\title{
W sprawie genezy i wieku form rzeźby glacjalnej pogranicza Wysoczyzn Kaliskiej i Tureckiej
}

\section{On the origin and age of the glacial landsystem on the border of the Kalisz and Turek Upland Plains}

Zarys treści: $\quad$ W latach 2012-2015 autorzy zebrali nowe dane geomorfologiczne i geologiczne na pograniczu Wysoczyzn Kaliskiej i Tureckiej, które pozwalają na uzupełnienie wiedzy na temat genezy i wieku form rzeźby. Ustalono, że większość glacigenicznych form wypukłych, tworzących tzw. strefę kaliską, powstała w brzeżnym pasie lądolodu zlodowacenia warty o kilkukilometrowej szerokości. Prawdopodobnie był to rezultat krótkotrwałego uaktywnienia lądolodu i szybkiej deglacjacji w pomaksymalnym epizodzie zlodowacenia warty, który nazwano w tym regionie subfazą bzury. Autorzy odrzucają jednocześnie możliwość transgresji na ten obszar lądolodu fazy leszczyńskiej zlodowacenia wisły.

Stwierdzono, że na przebieg procesów glacjalnych miały wpływ cechy morfologiczne, litologiczne i dynamika podłoża, w tym nawet wstrząsy sejsmiczne. Strukturę analizowanych form tworzą głównie osady stożków napływowych i glacifluwialnych rzek roztokowych. Część osadów objęta jest deformacjami o różnym zasięgu - w największym stopniu zaburzeniami tektoniki glacjalnej sensu lato. W strefie przypowierzchniowej występują także zaburzenia paraglacjalne i peryglacjalne o lokalnym zasięgu. Struktura większości form wypukłych jest charakterystyczna dla kemów glacifluwialnych diapirowych. Formy największe mają zwykle budowę złożoną zarówno pod względem litofacjalnym, jak i wiekowym, a jednoznaczne przyporządkowanie im wąskiej kategorii genetycznej (np. kem diapirowy, morena spiętrzenia, morena martwego lodu) może być nadmiernym uproszczeniem.

Słowa kluczowe: kemy, zlodowacenie warty, glacitektonika, deglacjacja, Wysoczyzna Kaliska, Wysoczyzna Turecka.

Abstract:

In the years 2012-2015, the authors collected new geomorphological and geological data on the borderline between the Kalisz and the Turek Upland Plains, which allow to make the understanding of the origin and age of the landscape forms more complete. It was established that most convex glacigenic forms which constitute the so called Kalisz zone originated in the several-kilometre-wide edge belt of the Wartanian ice sheet. It was probably the result of a short-term activation of the ice-sheet and rapid deglaciation in the post-maximal episode of the Wartanian glaciation, which was called the Bzura sub-phase in this region. At the same time, the authors reject the possibility of transgression to this area of the Leszno phase ice sheet of the Vistulian glaciation.

It was found that the course of glacial processes was influenced by morphological and lithological features as well as the dynamics of the bedrock, including seismic shocks. The structure of the analysed forms consists mainly of sediments of alluvial fans and glacifluvial braided rivers. Some sediments are deformed - in the largest degree by glacial tectonic disturbances sensu lato. In the near-surface zone, local paraglacial and periglacial disturbances also occur. The structure of most convex forms is characteristic of diapiric glacifluvial kames. The largest forms are usually complex both in terms of age and lithofacial features, and assigning them explicitly with a narrow genetic category (e.g. diapiric kame, push moraine or dead-ice moraine) may be an oversimplification.

Key words: $\quad$ kames, Warta Glaciation, glacitectonics, deglaciation, Kalisz Upland Plain, Turek Upland Plain.

\section{Wprowadzenie}

Formy glacjalne występujące na pograniczu Wysoczyzn Kaliskiej i Tureckiej (Kondracki 2001) były badane już wielokrotnie, lecz do dziś są one przedmiotem kontrowersji zarówno co do szczegółów interpretacji ich genezy, jak i wieku - w sensie przynależności do ostatniego lub przedostatniego zlodowacenia (rys. 1, 2). Dyskusja na temat przynależności form glacigenicznych obszaru do określonych typów genetycznych, jak i do poszczególnych pięter plejstocenu, trwa już ponad stulecie.

W latach 60. ubiegłego wieku wyrażano poglądy o występowaniu na obszarach niżowych, w tym na terenie Wielkopolski, zespołów rzeźby kemowej, powstałych w wyniku deglacjacji arealnej, zwanej też deglacjacją strefową (m.in. Bartkowski 1968). Również i w zasięgu obszaru opisywanego w niniejszym artykule, także dla terenów sąsiednich już od początku lat 70. wskazywano na przykłady rzeźby martwego lodu (m.in.:
Klatkowa 1972; Chrzanowski 1980; Kłysz 1981; Krzemiński 1997). Jednocześnie podtrzymywane były poglądy o genezie czołowomorenowej znacznej liczby występujących tu form wypukłych (Mańkowska 1980, 1983ab, 1985; Mańkowska, Gogołek 1988; Gogołek, Mańkowska 1989; Trzmiel 1995; Haisig, Wilanowski 2007). Należy także odnotować tezę o ostańcowym charakterze Wału Malanowskiego, którego fragment znajduje się w północnej części obszaru, przedstawioną przez Lencewicza (1927), a później rozwiniętą przez Dylika (1953) i Rotnickiego (1966). Zgodnie z koncepcją Dylika jest to ostaniec kadłubowy, utworzony w wyniku denudacji peryglacjalnej. Tezę o denudacji peryglacjalnej rozbudował jednak najbardziej Rotnicki (1966), który rozszerzył swe poglądy na większość form wypukłych dorzecza Prosny, co m.in. zaprezentował na mapie geomorfologicznej powstałej w 1965 roku (w wersji uproszczonej: Rotnicki 1966, s. 234, w wersji cyfrowej, uzupełnionej: Rotnicki 2011). 


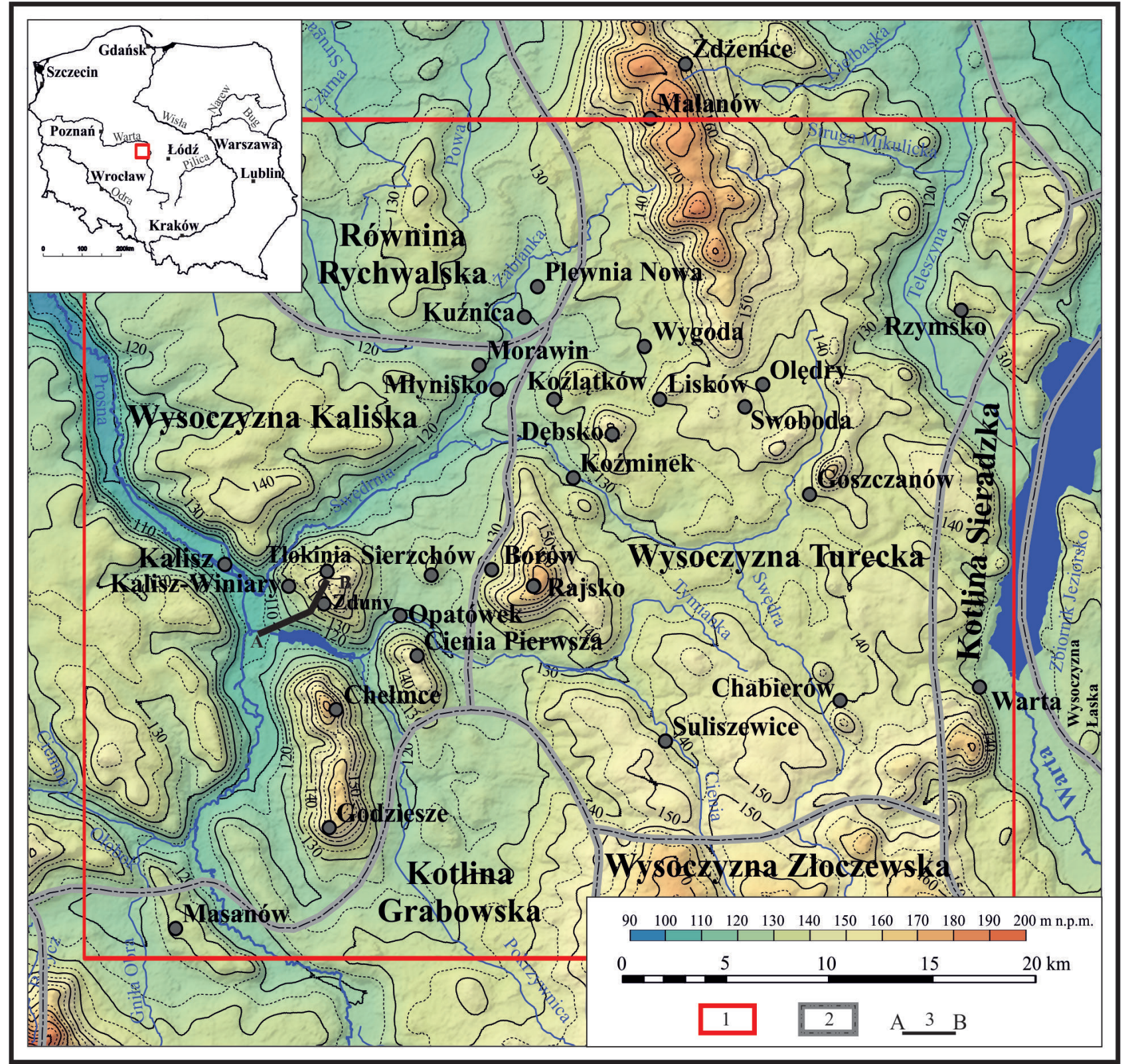

Rys. 1. Położenie obszaru badań na tle głównych rysów rzeźby terenu i mezoregionów fizycznogeograficznych według Kondrackiego (2001). Na mapie zaznaczono miejscowości wymienione w tekście. W opracowaniu rzeźby wykorzystano numeryczny model terenu (SRTM3) 1 - granice obszaru analizy, 2 - granice mezoregionów, 3 - linia przekroju AB (rys. 8)

Fig. 1. Location of the studied area within the context of major landscape features and physico-geographical mesoregions according to Kondracki (2001). Places mentioned in the text are marked on the map. Digital elevation model was used for drawing the relief (SRTM3) 1 - limits of the analysed area, 2 - mesoregion borders, 3 - AB cross-section line (fig. 8)

Dyskusję na temat wieku form opisali szczegółowo Petera i Forysiak (2003), odnosząc się do obszaru znacznie większego - mieszczącego się między Poznaniem a Uniejowem. Z przeglądu dotychczasowych prac wynika, że większość badaczy wiąże formy opisywanego obszaru ze zlodowaceniem (ew. stadiałem) warty, jednakże jeszcze niedawno wiązano powstanie niektórych form z zasięgiem maksymalnym lądolodu zlodowacenia wisły. Zdaniem Mańkowskiej (1980, 1983ab, 1985) faza leszczyńska miałaby tu zapisać się wąskim lobem, sięgającym na południe aż po okolice Koźminka (rys. 2).

Rzeźba terenu badań odznacza się przewagą falistych wysoczyzn morenowych i występowaniem pagórków, tworzących ciąg o przebiegu z SW na NE. Ich geneza jest w literaturze nadal przedmiotem dyskusji i kontrowersji.
Wysoczyzny morenowe rozcięte są doliną Prosny i dolinami jej dopływów; niewielka, północno-wschodnia część obszaru należy do zlewni Warty (rys. 1). Opisywany obszar, położony na pograniczu monokliny przedsudeckiej i niecki mogileńsko-łódzkiej, wykazuje w podłożu silnie rozczłonkowanie utworów piętra cechsztyńsko-mezozoicznego systemami uskoków.

Główne cele niniejszego artykułu stanowią:

- ustalenie, czy na genezę form glacigenicznych wpłynęły cechy morfologii, litologia oraz dynamika podłoża, głównie podłoża podplejstoceńskiego,

- zajęcie stanowiska na temat wieku rzeźby glacjalnej w świetle trwającej dyskusji w literaturze geomorfologicznej i geologicznej, 
- uzupełnienie i uściślenie danych dotyczących struktury wypukłych form glacigenicznych, wypowiedź na temat ich genezy oraz wskazanie ważniejszych problemów geomorfologicznych i paleogeograficznych do rozwiązania w dalszych badaniach.

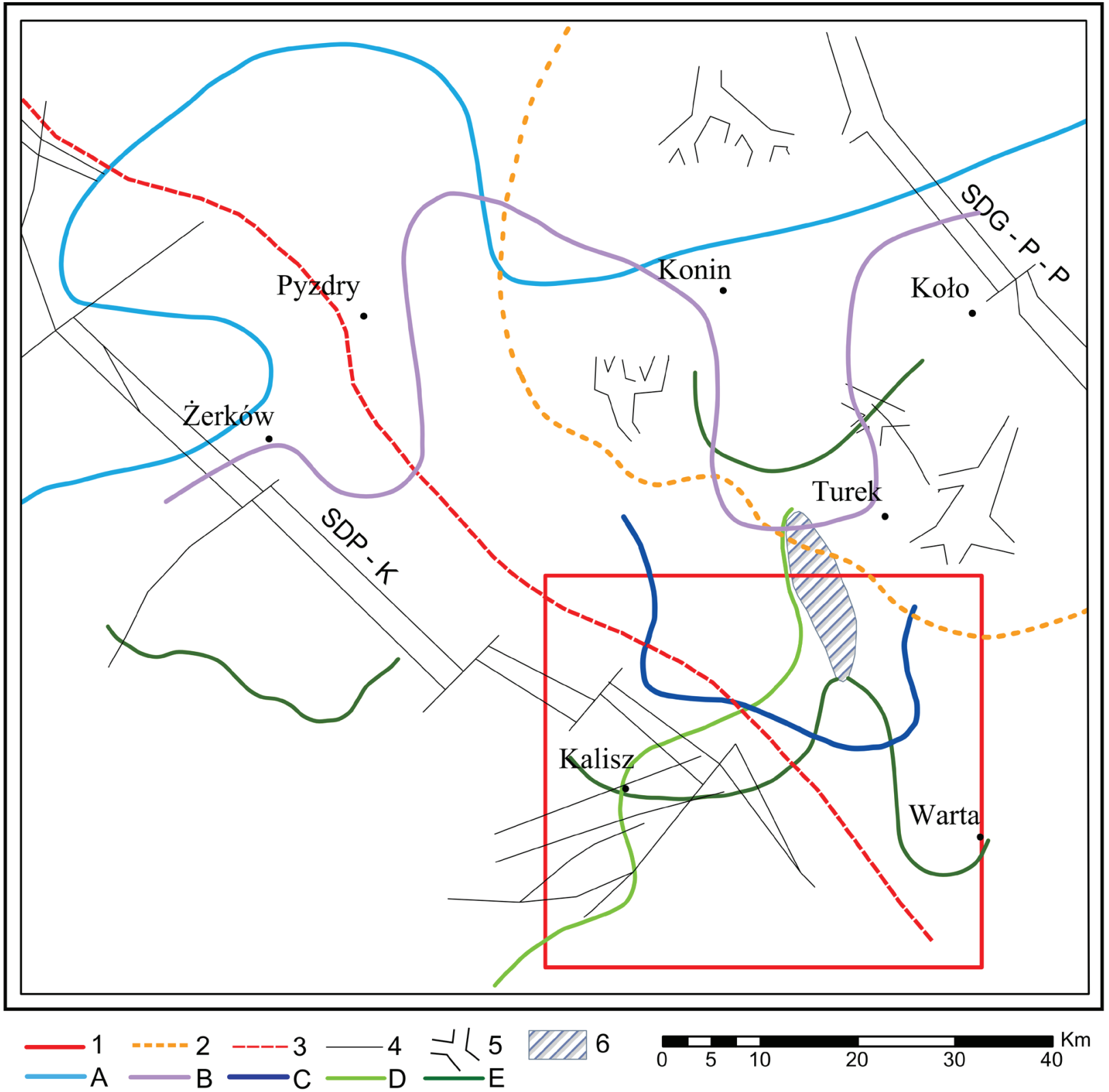

Rys. 2. Położenie obszaru badań na tle głównych elementów tektonicznych podłoża i zasięgów zlodowaceń (wybrane koncepcje) 1 - obszar badań, 2 - zasięg elewacji konińskiej, 3 - granica między monokliną przedsudecką i niecką łódzką, 4 - ważniejsze uskoki, 5 - rowy tektoniczne i inne strefy dyslokacyjne według Widery (2007): SDP-K - strefa Poznań-Kalisz, SDG-P-P - strefa Gopło-Ponętów-Pabianice, 6 - zasięg Wału Malanowskiego.

Wybrane zasięgi zlodowaceń: A - zasięg fazy leszczyńskiej według Majdanowskiego (1950), B - zasięg fazy leszczyńskiej według Domosławskiej-Baranieckiej (1969), C - zasięg fazy leszczyńskiej według Mańkowskiej (1980, 1983b), D - zasięg stadiału warty według Rotnickiego (1971), E - zasięg stadiału warty z okresu deglacjacji według Krygowskiego (1974)

Fig. 2. Location of the studied area with reference to major tectonic components of the bedrock and glaciation extents (selected concepts) 1 -studied area, 2 - Konin elevation extent, 3 - border between the Fore-Sudetic Monocline and the Łódź basin, 4 - significant faults, 5 - tectonic grabens and other dislocation zones according to Widera (2007): SDP-K - the Poznań-Kalisz zone, SDG-P-P - the Gopło-Ponętów-Pabianice zone, 6 - extent of the Malanów Ridge.

Selected glaciation extents: A - extent of the Leszno phase according to Mańkowska (1980, 1983b), B - extent of the Leszno phase according to Domosławska-Baraniecka (1969), C - extent of the Leszno phase according to Majdanowski (1950), D - extent of the Warta stage according to Rotnicki (1971), E - extent of the Warta stage during the deglaciation period according to Krygowski (1974) 


\section{Metody badań}

W latach 2012-2015 udokumentowano nowe odsłonięcia i zebrano różnorodne dane, które pozwalają poszerzyć dotychczasowe informacje geologiczno-geomorfologiczne i umożliwiają zajęcie stanowiska zarówno co do wieku form badanego obszaru, jak i interpretacji elementów ich budowy wewnętrznej oraz genezy. Część tych badań wykonano w ramach przygotowań pracy magisterskiej jednej z autorek (Tarnawska 2013), część zaś w ramach projektu badań statutowych Katedry Geografii Fizycznej UŁ: „Rekonstrukcje paleogeograficzne młodszego plejstocenu Polski Środkowej".

Podstawowych danych do opracowania dostarczyły badania terenowe: geomorfologiczne, sedymentologiczne i z zakresu geologii strukturalnej. Badane formy przeanalizowano pod względem morfometryczno-morfograficznym (m.in. badano rozmiary form, morfolineamenty, cechy jeziorności obszaru i gęstość występowania zagłębień bezodpływowych), sposobu ułożenia osadów, ich cech litologicznych oraz występowania i rodzaju deformacji. W opisie cech litologicznych osadów opierano się na kodzie litofacjalnym (Miall 1978; Eyles et al. 1983) w wersji zmodyfikowanej. Analizy teksturalne: uziarnienia metodą sitową, kształtu oraz obróbki ziarn metodą morfoskopową zostały wykonane w laboratorium Katedry Geografii Fizycznej i Wydziału Nauk Geograficznych Ut.

W badaniach wykorzystano metody GIS. Do prezentacji rzeźby użyto cyfrowego modelu terenu SRTM-3, zaś dla analiz morfometrycznych modelu CMT udostępnianego przez COD-GiK (o interwale siatki co najmniej 100 metrów), oraz map topograficznych w skali 1:10 000 i 1:25 000. Analizy morfometryczne wykonano w programie ArcGIS v. 9.1 i10.2.2., Quantum GIS v. 2.8 i starsze oraz Grapher v. 5 iSurfer v. 12 (Golden Software). Wykonano także pomiary i analizy kartometryczne z użyciem wielkoskalowych map topograficznych. W szczególności przeprowadzono analizy morfolineamentów w obrębie wypukłych form glacigenicznych oraz występowania zagłębień bezodpływowych o genezie przypuszczalnie glacigenicznej. Ryciny zostały opracowane w programie CorelDRAW X6 i Inkscape 0.91. Badania uzupełniono przeglądem regionalnej i tematycznej literatury geologicznej i geomorfologicznej.

\section{Wyniki analizy rzeźby i budowy geologicznej}

W części południowo-zachodniej obszaru badań do linii Sierzchów-Popów (monoklina przedsudecka), powierzchnię podkenozoiczną tworzą utwory jurajskie, dalej na NE (niecka mogileńsko-łódzka) występują różne piętra kredy (Baranowski, Mańkowska 1970, rys. 2). Powierzchnię podczwartorzędową budują utwory neogenu, miejscami usunięte, np. w części centralnej (wzdłuż linii: Suliszewice-Sierzchów-Koźlątków) i północno-wschodniej. Charakterystyczną cechą budowy geologicznej podłoża jest silne rozczłonkowanie utworów piętra cechsztyńsko-mezozoicznego systemami uskoków. Znajduje to wyraz w postaci szeregu bloków tego podłoża, wzajemnie przemieszczonych w wyniku dotychczasowej aktywności tektonicznej. Do charakterystycznych obiektów tektonicznych obszaru badań należy strefa dyslokacyjna Poznań-Kalisz i kilkukilometrowej szerokości rowy tektoniczne, położone na północny-wschód od Kalisza; stanowią one zachodni fragment lineamentu Poznań-Rzeszów (Widera 2007).
Powierzchnia podczwartorzędowa wykazuje znaczne urozmaicenie (rys. 3,4,5). Deniwelacje pomiędzy skrajnymi wartościami jej rzędnych dochodzą do $110 \mathrm{~m}$, osiągając podobne wartości jak zróżnicowanie rzeźby terenu. Obecna powierzchnia terenu wykazuje związki z ukształtowaniem starszego podłoża na przeważającej części analizowanego obszaru. W przekrojach południkowych zaznacza się ogólna tendencja do pochylenia na N obydwu tych powierzchni. Największe współczesne wzniesienia w dużym stopniu pokrywają się z najwyższymi elewacjami starszego podłoża; nie dotyczy to jednak Wału Malanowskiego, którego ukształtowanie nie wykazuje wyraźnego związku z formami podłoża. W rzeźbie podłoża wyróżnia się kilka większych obniżeń. Najgłębsze z nich przebiega mniej więcej przez środek opisywanego obszaru. Poziom jego dna znajduje się na wysokości 45-55 m n.p.m. Jak sugeruje Chrzanowski (1980), mogło ono powstać w efekcie przedczwartorzędowego odpływu wód Praprosny. Należy jednak zauważyć, że współczesna dolina Prosny ma w podłożu obniżenie dość wiernie odpowiadające jej przebiegowi. Inna forma typu dolinnego rozciąga się z SE na NW na linii: Warta-Goszczanów-Dębsko-Kuźnica. Dno tej formy położone jest poniżej 80 m n.p.m. Istnieje możliwość, że w pewnym okresie rozwoju rzeźby obszaru przepływały tędy wody Prawarty (Baranowski, Mańkowska 1972, 1979; Chrzanowski 1980). W obniżeniach z reguły występują osady czwartorzędu o większej miąższości niż w obrębie wysoczyzn.

Najstarsze utwory plejstoceńskie, przypisywane zlodowaceniu sanu (krakowskiemu), występują w postaci płatów glin lodowcowych, a ich miąższość w obrębie Wału Malanowskiego dochodzi nawet do $40 \mathrm{~m}$. Znaczne lub selektywne zniszczenie tych osadów w Polsce Środkowej przypisuje się erozji, przypuszczalnie najbardziej efektywnej w interglacjale mazowieckim (Baraniecka, Sarnacka 1971; Różycki 1972; Chrzanowski 1980; Kłysz 1981; Klatkowa 1988; Krzemiński, Bezkowska 1987; Klatkowa, Załoba 1991; Czyż i in. 2004, 2008).

Analiza materiałów archiwalnych i opracowań geologiczno-kartograficznych pozwala stwierdzić, że na obraz budowy geologicznej i ukształtowania obu wysoczyzn w decydujący sposób wpłynęły lądolody zlodowaceń odry i warty (w rozumieniu paleoglacjologicznym). Na przebieg tych nasunięć, niezależnie od przypisywanej im rangi klimatostratygraficznej miało wpływ ukształtowanie podłoża, które ukierunkowało napływ mas lodowych na analizowanym obszarze. Przewaga powierzchni pochylonych ku północy, w szczególności północny kierunek spadku den podłużnych obniżeń sprawiły, że w zastoiskach przed czołem nasuwającego się lądolodu zakumulowane zostały piaski, mułki i iły. Glina lodowcowa zlodowacenia odry występuje izolowanymi płatami, co przypisywane jest głównie skutkom degradacji przed nasunięciem warciańskim iwjego trakcie.Znaczne urozmaicenie podłoża na linii KaliszWał Malanowski mogło utrudniać transgresje lądolodów, w tym postmaksymalne transgresje lądolodu warciańskiego. Z uwagi jednak na miąższe osady plastyczne (m.in. pliocenu) i urozmaicenie podłoża, lądolód mógł łatwo zaburzać osady w różnych etapach swojego istnienia, a jednocześnie był prawdopodobnie bardziej podatny na zanik arealny w tej strefie.

Rzeźba terenu badań charakteryzuje się przewagą wysoczyzn morenowych o zmiennym urozmaiceniu: płaskich, falistych (dominujących pod względem powierzchni) i pagórkowatych (rys. 6). Pas wysoczyzn, najbardziej uroz- 


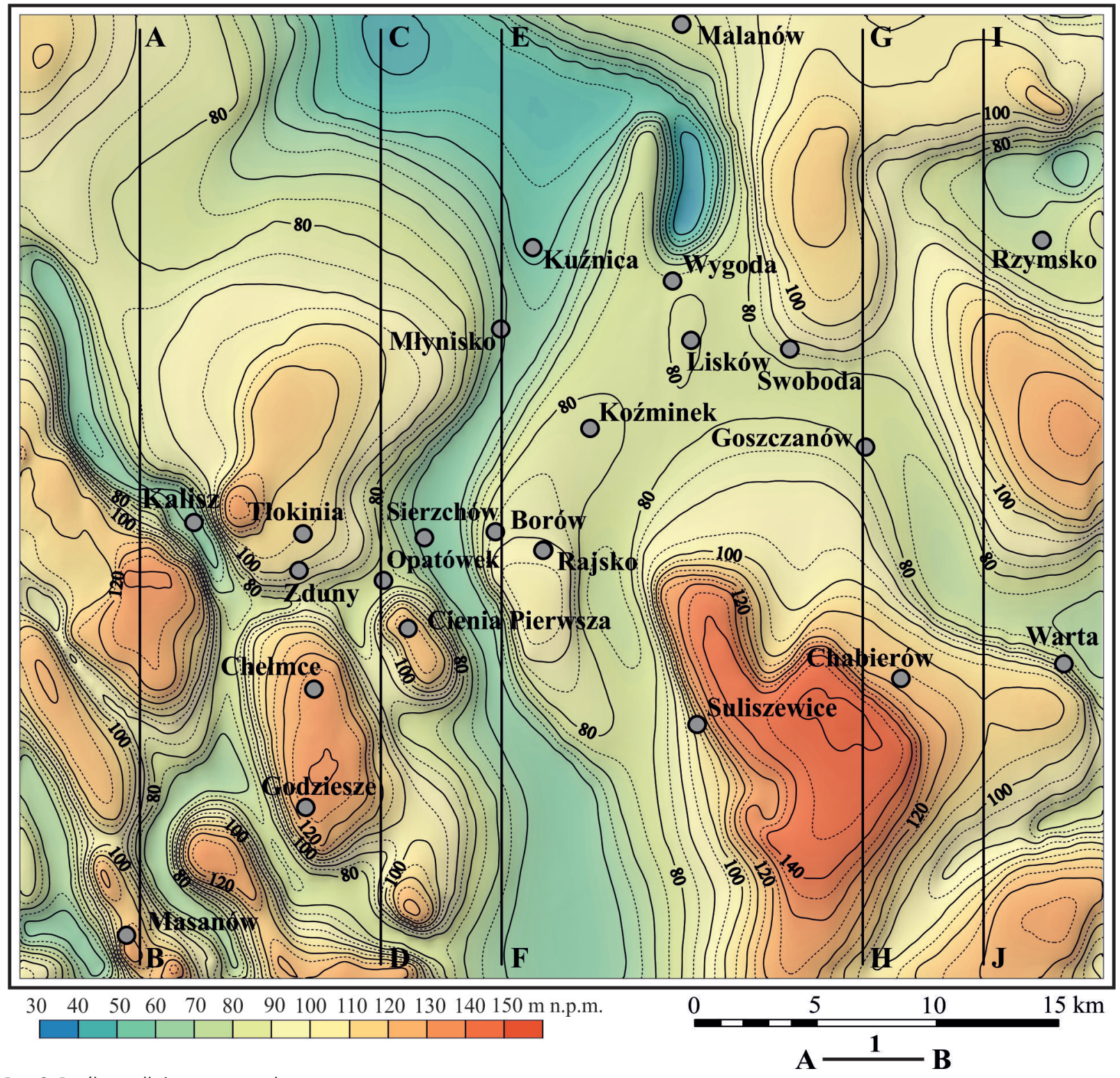

Rys. 3. Rzeźba podłoża czwartorzędu

1 - linie profili rzeźby podłoża i rzeźby współczesnej, przedstawionych na rys. 5 . Izolinie co $5 \mathrm{~m}$.

Opracowanie głównie na podstawie materiałów Mapy geologicznej Polski 1:200 000 (Baranowski, Mańkowska 1972)

Fig. 3. Relief of the Quaternary bedrock

1 - profile lines of the bedrock and contemporary reliefs, presented in fig. 5 . Contour lines every $5 \mathrm{~m}$.

Based mostly on the contents of the 1:200 000 geological map of Poland (Baranowski, Mańkowska 1972)

maicony ciągiem pagórków, wałów i wzgórz, biegnie z SW na NE na linii Masanów-Godziesze-Swoboda w kierunku południowego obrzeżenia Wału Malanowskiego. W czasie badań terenowych przeanalizowano wybrane formy, a w ich obrębie stanowiska, które stanowiły odsłonięcia eksploatacyjne.

W trakcie analizy rzeźby uwzględniono 33 glacigeniczne formy wypukłe. Wysokości względne analizowanych form są zróżnicowane i dochodzą maksymalnie do 48,3 m. Największe deniwelacje występują w okolicy miejscowości Rajsko. Średnia wysokość form wynosi 13,7 m. Długość form waha się od 170 m (okolice Kolonii Ubigórki) do 7,6 km (okolice Rajska). Najwięcej z nich, tj. 18 form (55\%), nie przekracza długości $1 \mathrm{~km}$. Osie morfologiczne badanych form najczęściej cechują się przebiegiem równoleżnikowym (12 form). Spośród pozostałych pagórków i wałów, 6 wyróżnia się przebiegiem osi: SW-NE, a 5 zorientowanych jest w sektorze NW-SE. Tylko 3 formy wykazują przebieg południkowy.

Ważnym etapem analizy rzeźby było kartowanie zagłębień bezodpływowych o hipotetycznej pierwotnej genezie glacjalnej - zarówno suchych, jak i wypełnionych wodą. W szczególności zwrócono uwagę na zróżnicowanie gęstości występowania zagłębień po obu stronach linii zasięgu fazy leszczyńskiej proponowanego przez Mańkowską (1980, 1983, rys. 2). Granica ta nawiązuje do przebiegu środkowego odcinka doliny Swędrni. Przeprowadzona analiza rzeźby na podstawie map topograficznych 1:10 000 i zdjęć lotniczych nie dowiodła istnienia znaczących różnic gęstości tych form na domniemanym zapleczu tak wyznaczonej fazy leszczyńskiej. Należy także zauważyć, że inne wyróżniki cech rzeźby (osie morfologiczne form glacjalnych i pozostałe morfolineamenty), również nie wspierają koncepcji Mańkowskiej (op. cit.). 


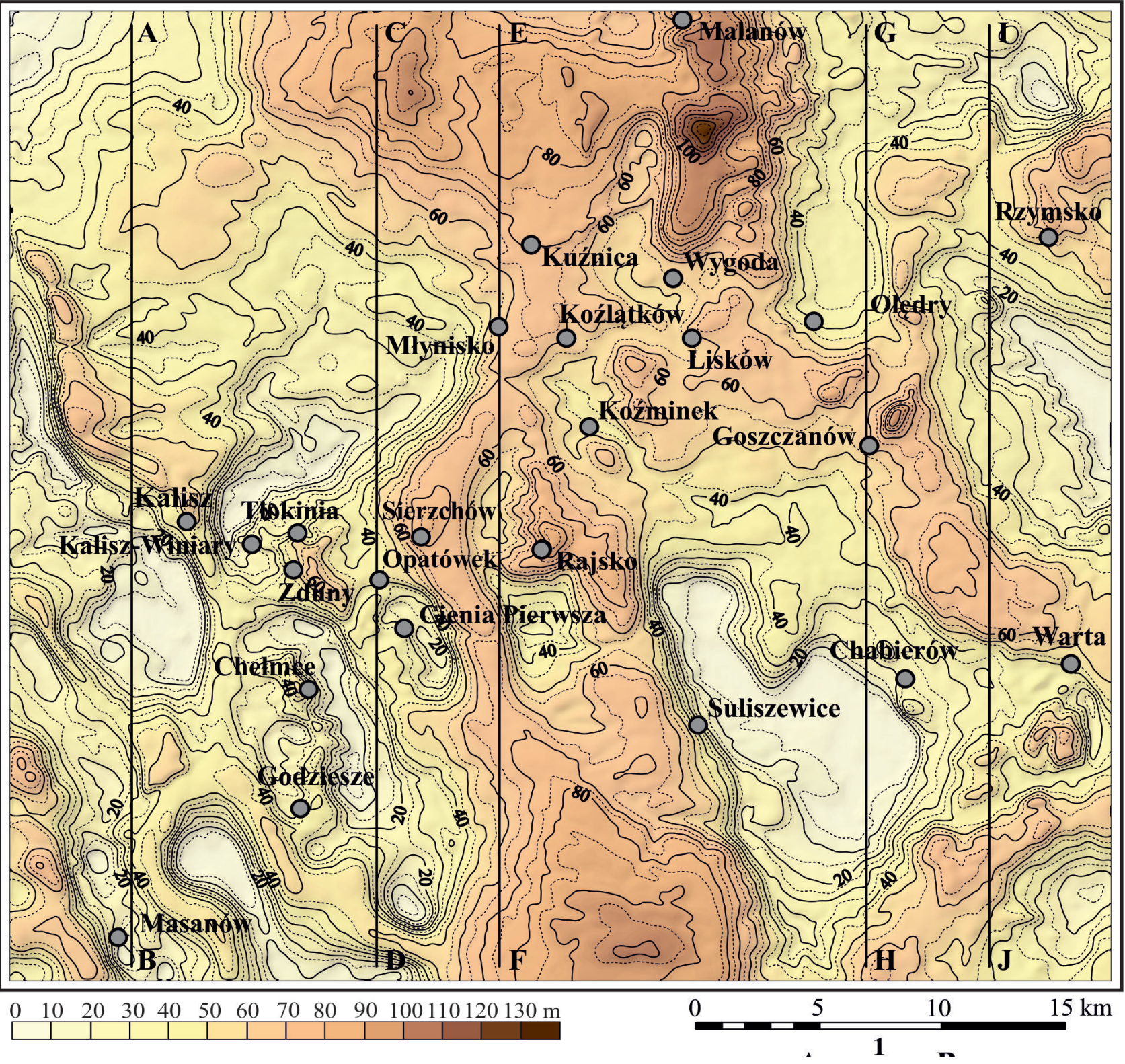

Rys. 4. Miążzzość utworów czwartorzędowych

1 - linie profili rzeźby podłoża i rzeźby wspótczesnej, przedstawionych na rys. 5. Izolinie co $5 \mathrm{~m}$. Opracowanie głównie na podstawie materiałów Mapy geologicznej Polski 1:200 000 (Baranowski, Mańkowska 1972)

Fig. 4. Quaternary thickness

1 - profile lines of the bedrock and contemporary reliefs, presented in fig. 5 . Contour lines every $5 \mathrm{~m}$. Based mostly on the contents of the 1:200 000 geological map of Poland (Baranowski, Mańkowska 1972)

Najmłodsze osady glacigeniczne akumulacji bezpośredniej ze zlodowacenia warty reprezentowane są zazwyczaj jedną warstwą gliny lodowcowej o miąższości od kilku do kilkunastu metrów. Większe, bardziej masywne jej płaty występują w obrębie wysoczyzn, np. dość jednolity i rozległy pokład rozpościera się na $\mathrm{N}$ od Kalisza w międzyrzeczu Prosny i Czarnej Strugi, gdzie tworzy współczesną powierzchnię terenu. W strefach większych dolin glina ta traci zwykle ciągłość, często zanurza się pod grubiejące osady glacifluwialne. W budowie pagórków i wzgórz występuje w ich dolnych częściach wyspowo, a w ogólnej kubaturze osadów zdecydowanie przewagę mają osady glacifluwialne. Nie napotkano form utworzonych marginalnie lub suglacjalnie z gliny (pomijając masywy wysoczyznowe).
W części form wzgórz i pagórków złożonych spotyka się zestawy litofacji zbudowane częściowo z diamiktonów i utworów glacifluwialnych, które mogą być efektem akumulacji w strefie kontaktu z lodem żywym lub martwym (fot. 1). Nie znaleziono jednak pojedynczej formy wypukłej, która byłaby zbudowana wyłącznie z tego typu osadów.

Przegląd struktur sedymentacyjnych w dostępnych odsłonięciach w obrębie pagórków, wałów i wysokich poziomów terasowych, towarzyszących dolinom i większym formom glacigenicznym obszaru, wykazuje dominację warstwowanych przekątnie utworów glacifluwialnych, piaszczysto-żwirowych. Regułą jest przewaga struktur tabularnych nad rynnowymi, nawet pośród gruboklastycznych i miąższych litofacji w ozie Rzymska (fot. 2). W nielicznych 
profilach stwierdzano przewagę struktur rynnowych nad tabularnymi (np. rys. 7, profil 1).

We frakcji żwirowej zwraca uwagę znaczny udział materiału miejscowego podłoża kredowego (otoczaki wapieni marglistych, margli wapnistych - „opok”). W odsłonięciu Rzymsko (na E granicy obszaru), w osadach ozu ustalono ich udział na $84 \%(N=100)$ w stosunku do materiału skandynawskiego $\mathrm{w}$ przykładowej próbce z litosomu żwirowego.
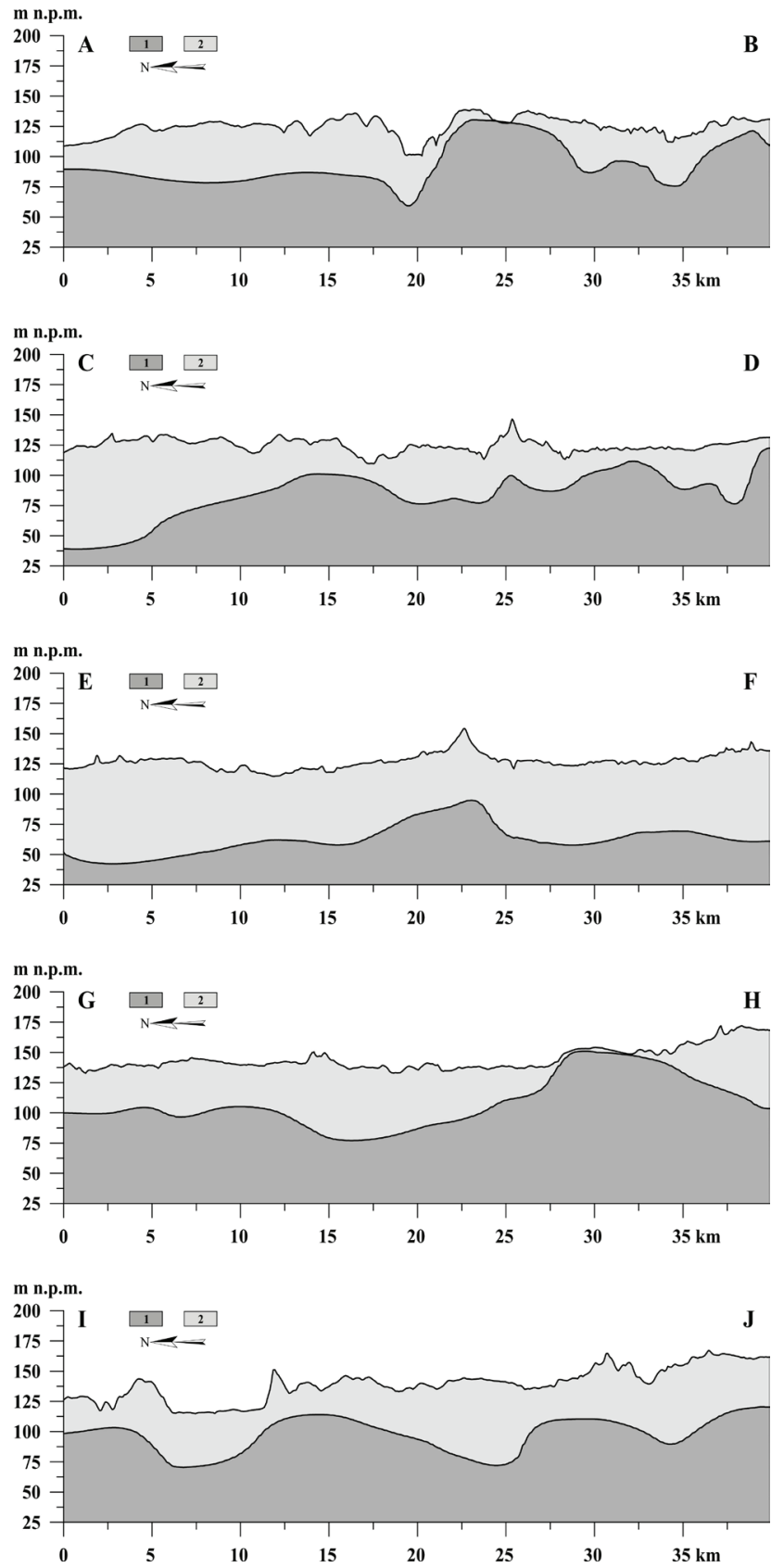

Rys. 5. Porównanie profili podłoża czwartorzędu i współczesnej rzeźby na podstawie materiałów Mapy geologicznej Polski 1:200 000 (Baranowski, Mańkowska 1972) oraz cyfrowego modelu wysokościowego CODGiK o interwale siatki co najmniej 100 m (por. rys. 3 i 4).

1 - osady czwartorzędu, 2 - osady podłoża czwartorzędu

Fig. 5. Comparison of profiles of the Quaternary bedrock and contemporary relief based on the contents of the 1:200 000 geological map of Poland (Baranowski, Mańkowska 1972) and the CODGiK digital elevation model with mesh interval of at least $100 \mathrm{~m}$ (cf. fig. 3 and 4). 1 - Quaternary sediments, 2 - Quaternary bedrock sediments

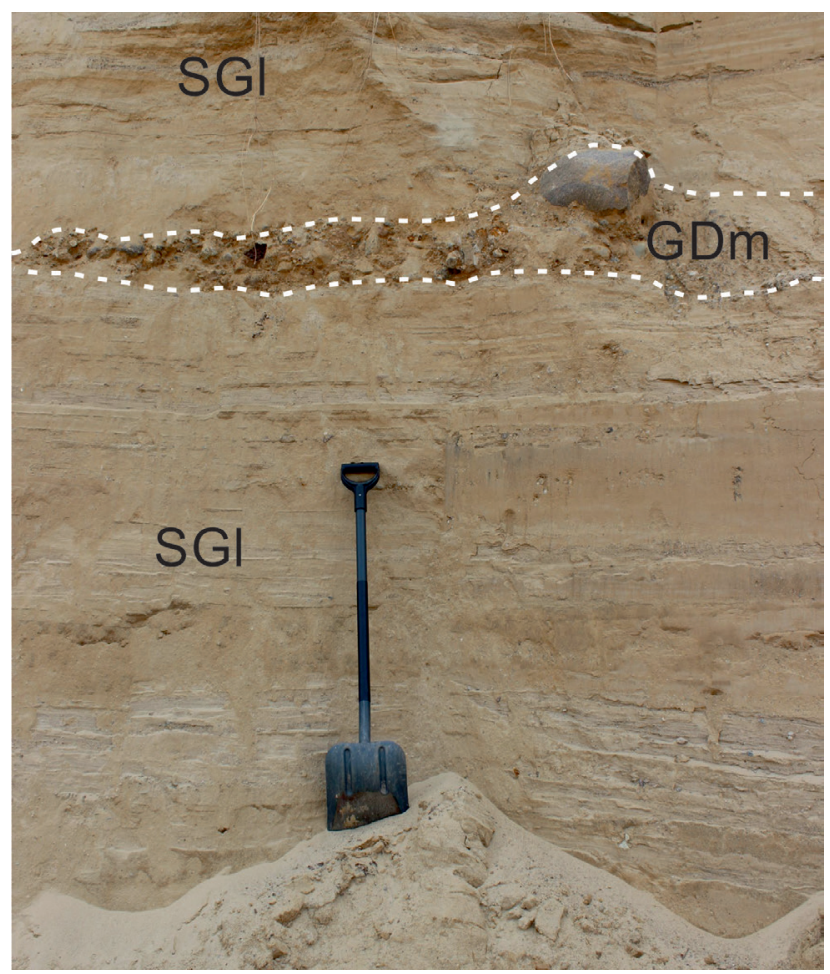

Fot. 1. Cienia III. Budowa stożka glacifluwialno-ablacyjnego (marginalnego) - część glacigenicznej formy o morfologii terasy kemowej. GDm - diamikton żwirowy jęzora spływu gruzowo-błotnego, SGI - piaski ze żwirem stożka napływowego (fot. Frydrych 2015)

Photo 1. Cienia III. Structure of a glacifluvial-ablation (marginal) fan part of a glacigenic form with the morphology of a kame terrace. GDm - gravelly diamictone of the stream of debris-mud flow, $\mathrm{SGI}$ - sands with gravel of the alluvial fan (photograph by Frydrych 2015)

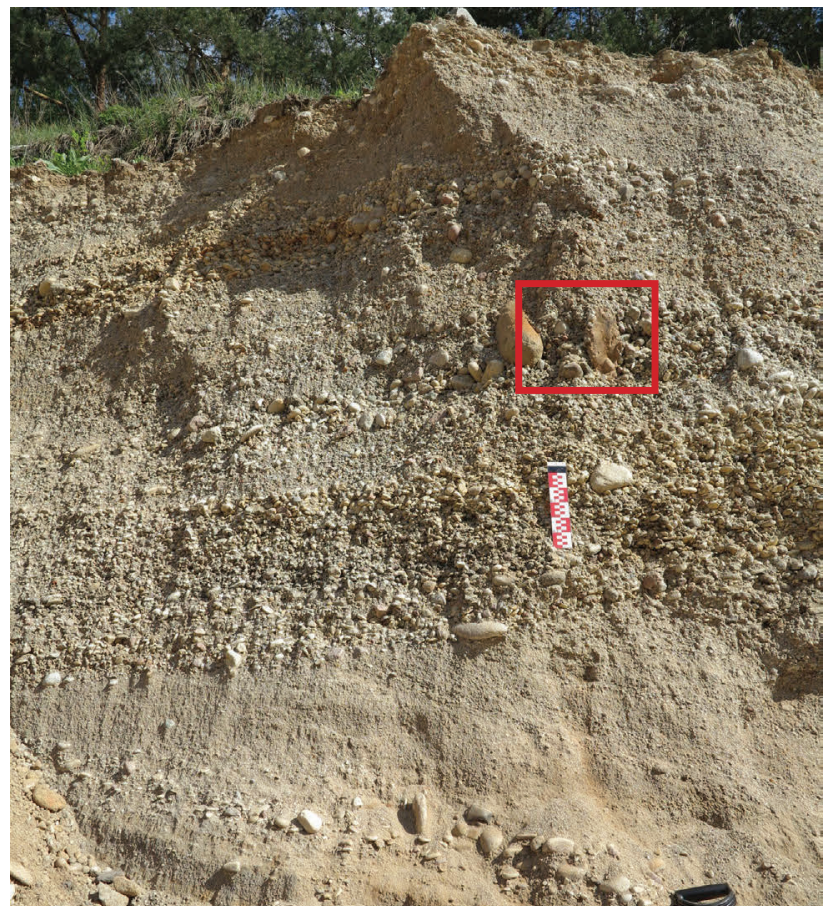

Fot. 2. Oz Rzymska. Wielkoskalowe warstwowanie przekątne żwirów. Prostokątem oznaczono fragment litosomu żwirowego z toczeńcem, przedstawionym w powiększeniu na fot. 3 (fot. Rdzany 2015)

Photo 2. Rzymsko Esker. Large scale diagonal stratification of gravels. Rectangle marks a fragment of gravelly lithosome with a till ball, presented in magnification in Photo. 3 (photograph by Rdzany 2015) 


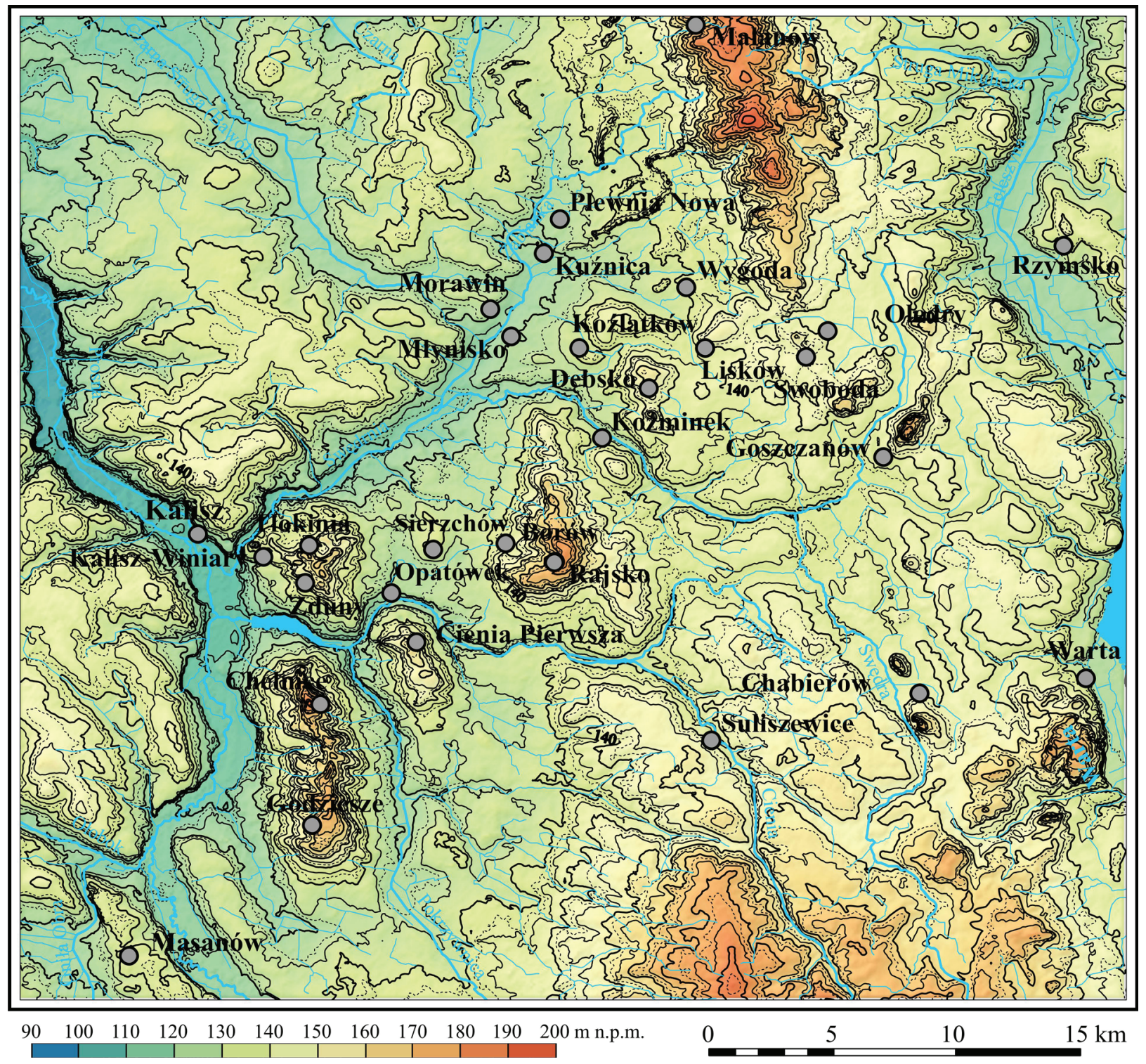

Rys. 6. Rzeźba terenu. Mapa wygenerowana w ArcGIS na podstawie cyfrowego modelu wysokościowego CODGiK o interwale siatki co najmniej $100 \mathrm{~m}$. Izolinie co $2,5 \mathrm{~m}$

Fig. 6. Topographic map. Map generated in ArcGIS on the basis of the CODGiK elevation model with mesh interval of at least 100 m. Contour lines every $2.5 \mathrm{~m}$

Osady zbiornikowe występują akcesorycznie. Dominują mułki z przewarstwieniami piasku i iłu, często masywne. W głębszych partiach profili niekiedy stanowią one warstwy o kilkumetrowej miąższości, lecz najczęściej są tam zdeformowane. Dość często spotyka się pośród osadów glacifluwialnych, szczególnie na granicach zestawów lamin, toczeńce gliniaste, mułkowe lub ilaste (fot. 3). Część z nich układa się w rzędy nawiązujące do powierzchni erozyjnych, część umiejscowiona jest w sposób chaotyczny. Ich charakter i położenie pozwalają przypuszczać, że zdeponowane zostały w czasie wzrostu tempa ablacji, przy szybkiej, intensywnej akumulacji piaszczysto-żwirowej. Miejsca ich wyerodowania znajdowały się w niewielkiej odległości.

Podobne cechy litologiczne stwierdzono również w formach, które przypisywano dawniej ostatniemu piętru zimnemu. Jako przykład takiej formy wybrano poziom terasowy u zbiegu doliny Prosny i Pokrzywnicy, w górnej bliskiej wysoczyźnie - części stoków doliny. Tworzy on po- wierzchnię wzniesioną od 125 do 130 m n.p.m., łagodnie nachyloną na SW - w kierunku centrum kotlinowatego rozszerzenia doliny Prosny przy wylocie doliny Pokrzywnicy. Stoki tej formy opadają na wyższy poziom terasy fluwialnej vistuliańskiej, który sięga tutaj do 120 121 m n.p.m. Genezę tego poziomu Rotnicki $(1966,2011)$ wiąże $\mathrm{z}$ denudacją peryglacjalną $\mathrm{w}$ vistulianie. Haisig i Wilanowski (2007) wyróżniają tu piaski i żwiry wodnolodowcowe zlodowacenia warty. Stanowią one przedpole wydłużonych pagórków, położonych między Kaliszem a Opatówkiem, określonych jako moreny wyciśnięcia. W obrębie wysokiego poziomu terasowego w stanowisku Kalisz-Winiary przeprowadzono badania kilkunastometrowej serii piaszczystej, spoczywającej - częściowo - na glinie zlodowacenia warty (rys. 8). Udokumentowano głównie osady piaszczyste. Pośród nich przeważają piaski średnioziarniste o wysortowaniu - według wskaźnika Folka i Warda (1957) - od słabego po umiarkowanie dobre, niekiedy z domieszką żwirów, a podrzędnie mułki. 


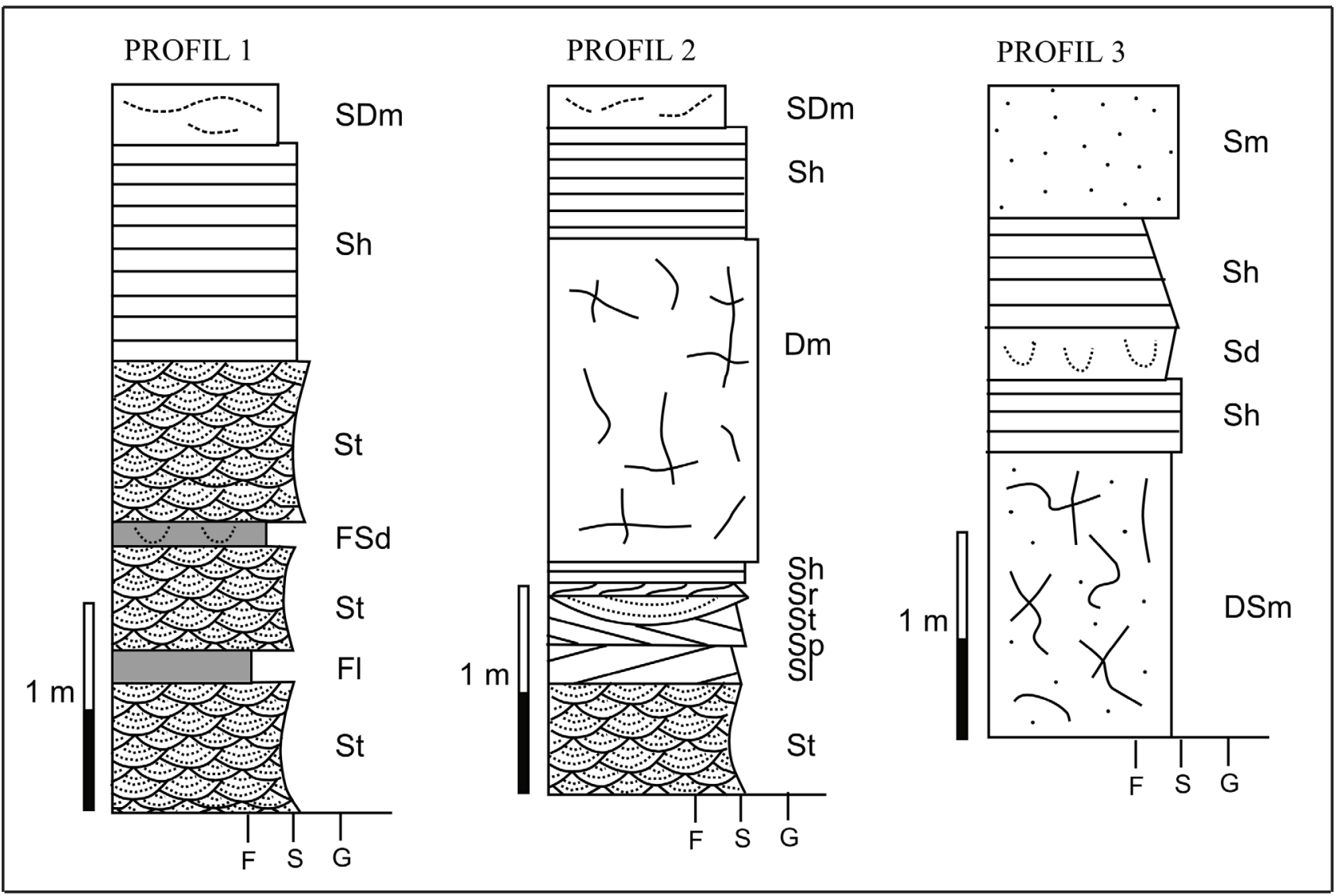

Rys. 7. Profile litofacjalne osadów glacifluwialnych w stanowiskach: Opatówek (1, 2) i Cienia III (3)

Kod litofacjalny: uziarnienie: $\mathrm{F}$ - mułek, S - piasek, G - żwir, D - diamikton; struktura: $\mathrm{m}$ - masywna, $\mathrm{d}$ - deformacyjna, I- warstwowanie niskokątowe, $\mathrm{h}$ - laminacja horyzontalna, $\mathrm{t}$ - warstwowanie rynnowe, $\mathrm{p}$ - warstwowanie płaskie, $\mathrm{r}$ - struktury riplemarkowe

Fig. 7. Lithofacial profiles of glacifluvial sediments at sites in Opatówek (1, 2) and Cienia III (3)

Lithofacies codes: grain-size distribution: F - silt, S - sand, G - gravel, D - diamictone; structure: $m$ - massive, $d$ - deformed, I - low angle stratification, $\mathrm{h}$ - horizontal lamination, $\mathrm{t}$ - trough stratification, $\mathrm{p}$ - flat stratification, $\mathrm{r}$ - ripplemark structures

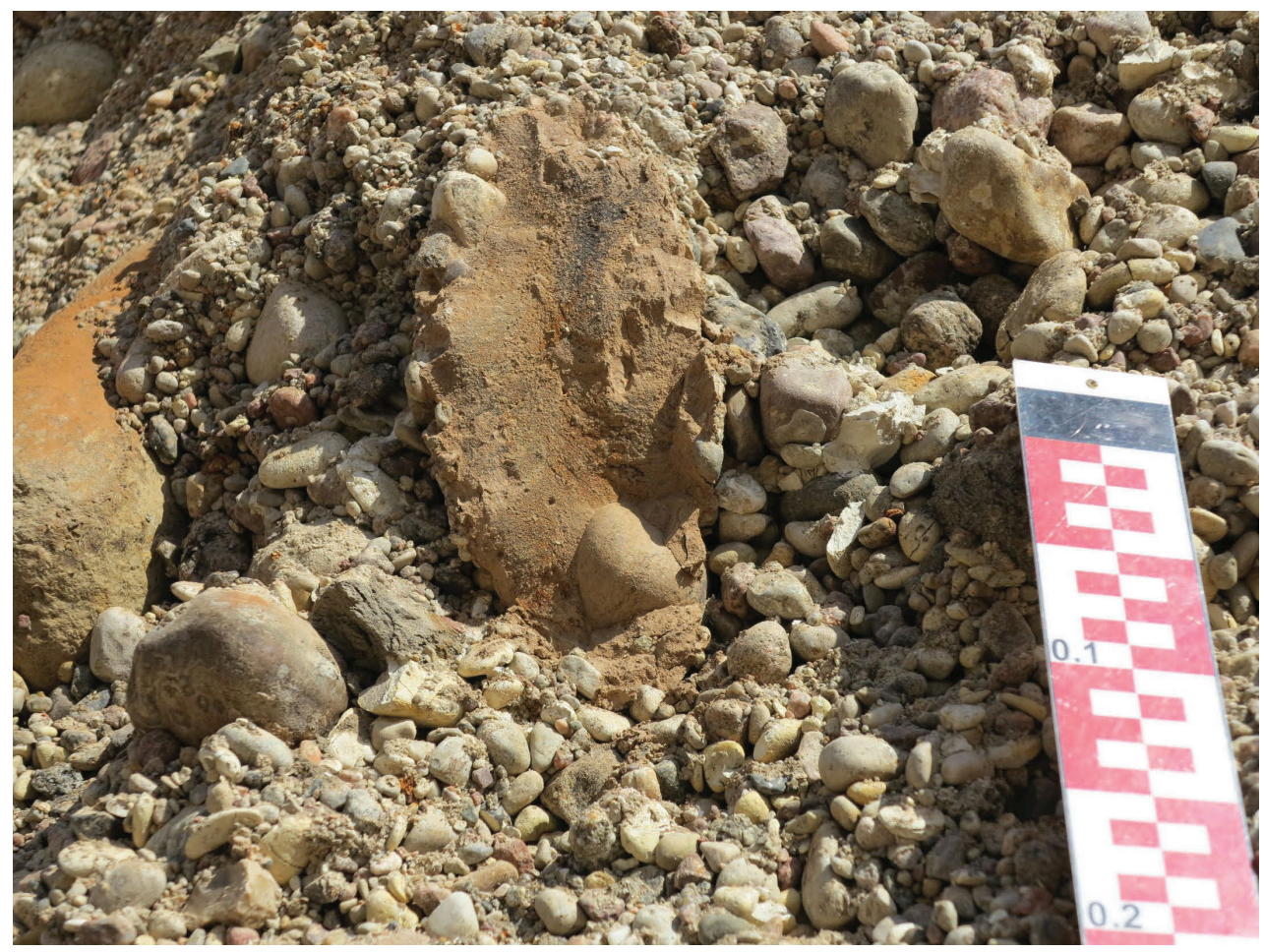

Fot. 3. Oz Rzymska. Toczeniec gliniasty uzbrojony w litosomie żwirowym. Fragment odsłonięcia przedstawionego na fot. 2 (fot. Rdzany 2015)

Photo 3. Rzymsko Esker. Armored till ball in gravelly lithosome. Fragment of the exposure presented in Photo. 2 (photograph by Rdzany 2015) 


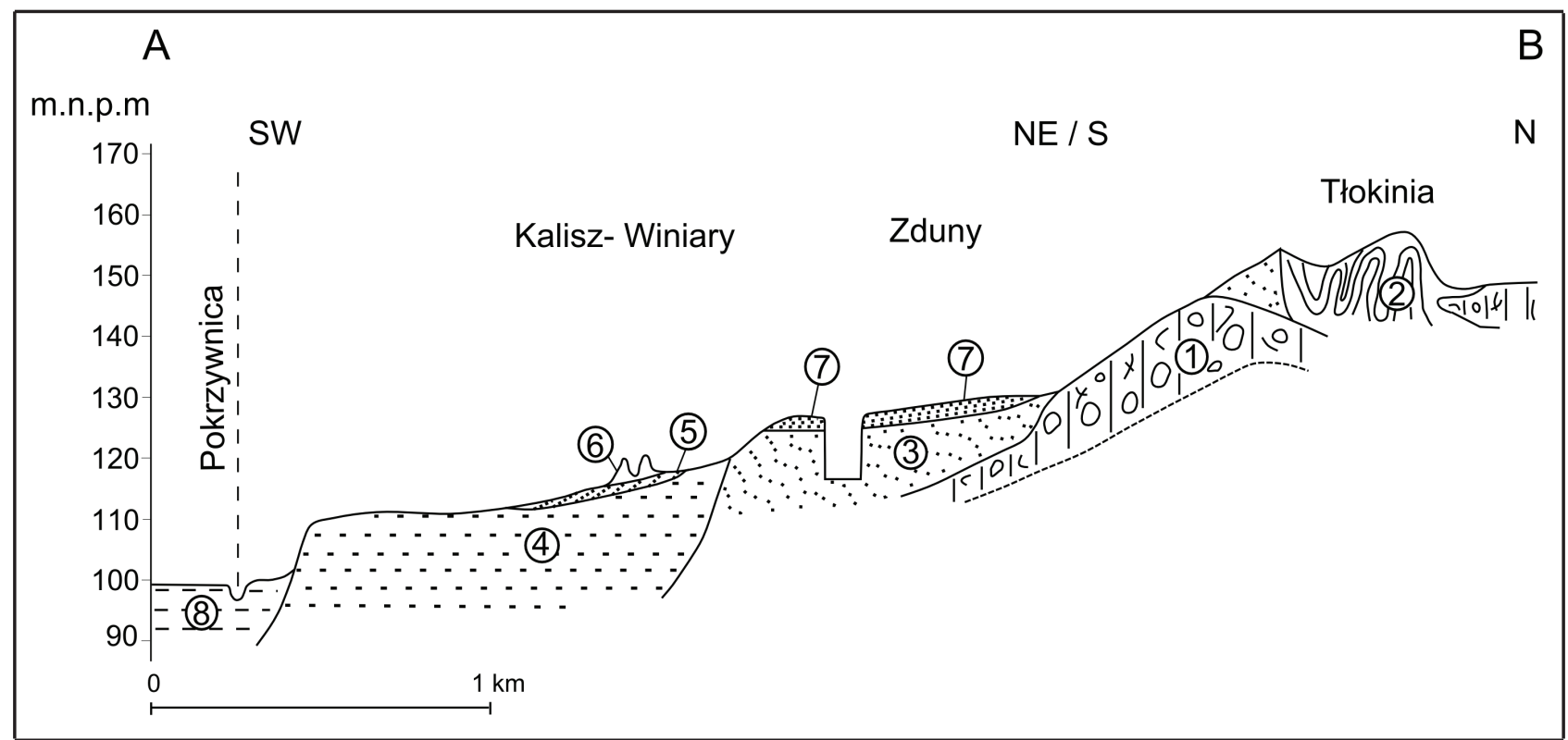

Rys. 8. Przekrój syntetyczny przez wysoki poziom terasowy (terasę kemową) w kotlinie dolinnej Prosny i Pokrzywnicy. Linię przekroju zaznaczono na rys. 1

Warta: 1 - glina lodowcowa, 2 - piaski, diamiktony, mułki i iły moren wyciśnięcia (geneza wg Haisiga i Wilanowskiego 2007), 3 - piaski glacifluwialne wysokiego poziomu terasowego (terasy kemowej); według Rotnickiego (2011): terasa III z fazy leszczyńskiej. Vistulian: 4 - piaski niższej i wyższej terasy nadzalewowej; terasa IV według Rotnickiego (2011) z fazy poznańskiej, 5 - bruk żwirowy z eologliptolitami, nieciągły. Późny vistulian: 6 - piaski wydm i pokryw eolicznych. Późny vistulian-holocen: 7 -diamiktony, żwiry i pyły. Holocen: 8 - piaski i mułki terasy zalewowej

Fig. 8. Synthetic cross-section through a high terrace level (kame terrace) in the valley basin of the Prosna and Pokrzywnica rivers. The profile line is marked in fig. 1

Warta: 1 - glacial till, 2 - sands, diamictones, silts and clays of the push moraines (genesis according to Haisig and Wilanowski 2007), 3 - glacifluvial sands of the high terrace level (kame terrace); according to Rotnicki (2011): terrace III of the Leszno phase. Vistulian: 4 - sands of the lower and higher flood terrace; terrace IV according to Rotnicki (2011) of the Poznan phase, 5 - gravely pavement with ventifacts, discontinuous. Late Vistulian: 6 - sands of dunes and eolian covers. Late Vistulian-Holocene: 7 - diamictones, gravels and dusts. Holocene: 8 - sands and silts of the flood terrace

Na diagramie C/M Passegi i Byramjee (1969) próbki z analizowanych utworów zajmują głównie pola I (55\%), IV (29\%) i V (13\%), co oznacza, że dominowała depozycja z trakcji z niewielkim udziałem zawiesiny (I), a znacząca część osadów pochodziła z zawiesiny gradacyjnej, powstałej w warunkach dużej i umiarkowanej turbulencji. Osady te odznaczają się zatem dominacją uziarnienia, charakterystyczną dla dynamiki środowiska rzek roztokowych glacifluwialnych. Analiza struktur sedymentacyjnych wskazuje na przewagę zestawów warstwowania przekątnego tabularnego, które jest lokalnie przedzielone - zwykle pojedynczymi - zestawami warstwowania rynnowego i rzadziej horyzontalnego (mułki i piaski drobnych zbiorników, żwiry - z zalewów warstwowych). Jak wynika z pomiarów upadów lamin warstwowania przekątnego, wody kierowały się głównie na SW, a więc do kotlinowatego obniżenia ProsnyPokrzywnicy (rys. 9B).

Cechy litologiczne osadów potwierdzają znaczne gradienty przepływów wód roztopowych: od nisko- do wysokoenergetycznych. W profilach występuje także zapis zróżnicowania głębokości strumienia, jednak były to na ogół głębokości niewielkie: od kilku do kilkudziesięciu cm, rzadko - powyżej $1 \mathrm{~m}$ (fot. 4). Występowały głównie skanalizowane przepływy korytowe, lecz dochodziło także do płytkich, rozproszonych zalewów warstwowych. Wyrazem przepływów wysokoenergetycznych są aluwia żwirowe, zaś w trakcie przepływów niskoenergetycznych dochodziło do depozycji aluwiów piaszczystych, które dominują. Wymienione cechy sedymentacji są typowe dla środowiska fluwialnego typu roztokowego, w szczególności glacifluwialnego, częściowo są to warunki rozległych stożków napływowych. W warstwach o niewielkiej miąższości (najczęściej do kilku cm) występują akcesorycznie pomiędzy litofacjami piaszczystymi mułki masywne i laminowane. Świadczą one o istnieniu przez krótki okres niewielkich zbiorników wód stojących.

Cechy budowy wewnętrznej badanej formy wskazują, że posiada ona cechy terasy kemowej, powstałej na SW od pagórków w okolicach Kalisza i Opatówka, określonych przez Haisiga i Wilanowskiego (2007) jako moreny wyciśnięcia. Jej osady powstawały w warunkach wysokiego położenia bazy erozyjnej w kotlinowatym węźle dolinnym na południe od Kalisza. Jest prawdopodobne, że wówczas to szerokie obniżenie dolinne (ok. $7 \mathrm{~km}$ na linii SulisławiceZduny), sięgające swym obrzeżeniem po linię: Kalisz (południowa część)-Sulisławice-Żydów-Wolica-Trojanów-Zduny, wypełnione było lodem lodowcowym - stagnującym lub martwym. Po jego częściowym stopieniu wody dość szybko zaczęły płynąć na znacznie niższych poziomach, odsłaniając w górnej, brzeżnej części obniżenia rodzaj terasy. Cechy tej formy i pozycja morfologiczna jest podobna do wysokich poziomów terasowych w kotlinowatym rozszerzeniu doliny górnej Rawki między Głuchowem, Radwanką i Rawą Mazowiecką (Rdzany 1997).

Po uformowaniu terasy dopływające tu wody roztopowe - już o mniejszej dynamice - często stagnowały na płaskiej powierzchni terasowej, czego efektem były liczne litofacje związane z wypełnieniem drobnych zbiorników, a niekiedy kałuż (fot. 5). Zostały one objęte procesami deformacji typu: paraglacjalnego pod koniec deglacjacji (por. Rdzany 2015), peryglacjalnego w vistulianie oraz późniejszym procesom glebotwórczym. Najpewniejszym 

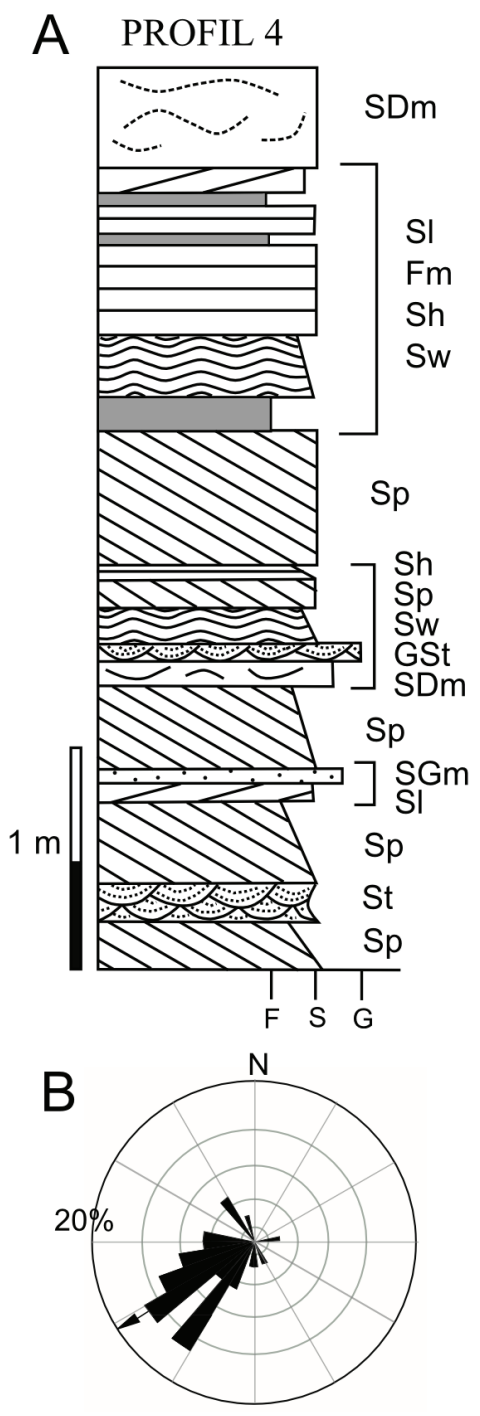

$\mathrm{N}=32$

Fisher Mean $\mathrm{Vec}=244^{\circ}$

Average lenght - 0,7972

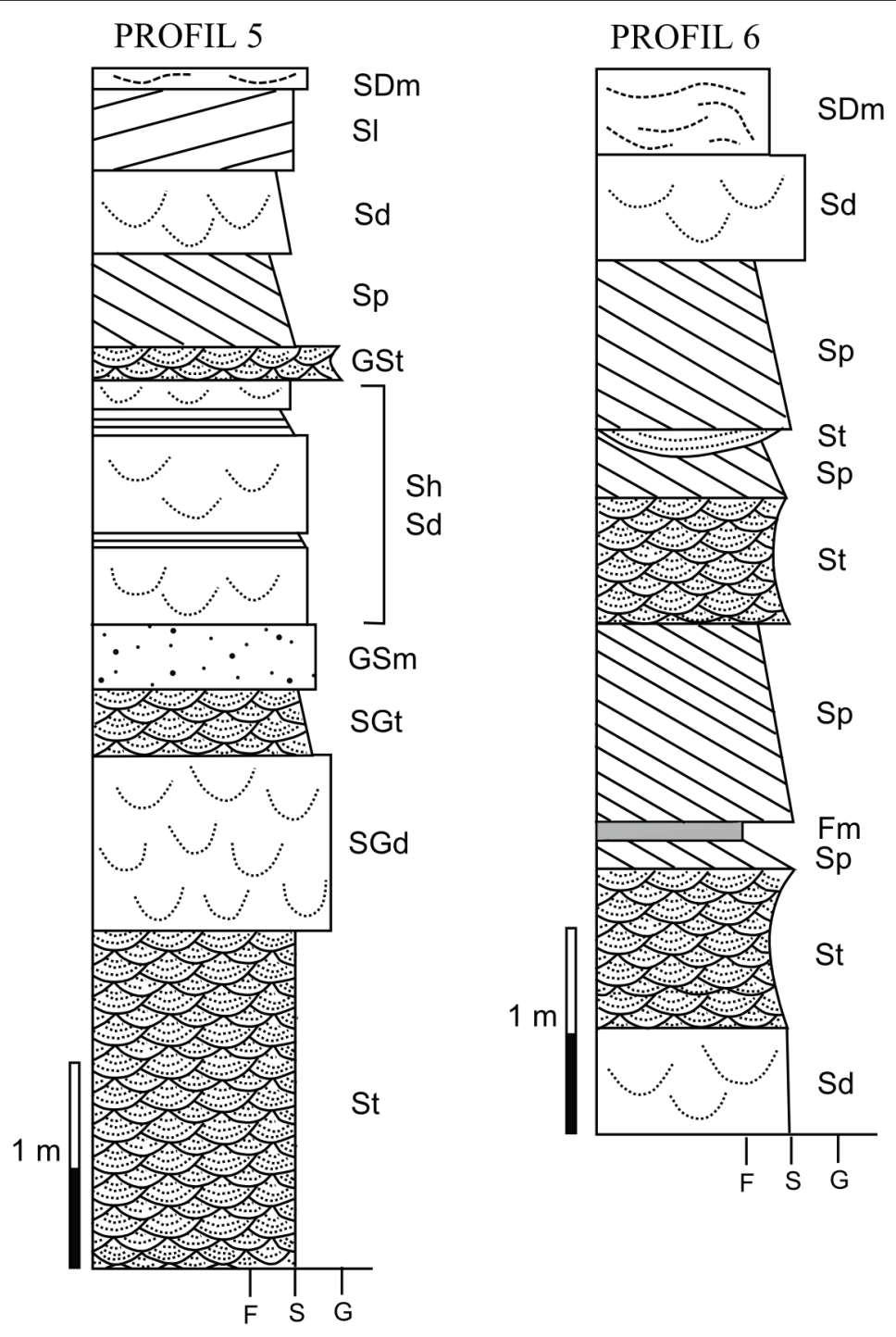

Rys. 9. Cechy litologiczne osadów w stanowisku Kalisz-Winiary (rys. 8, seria 3)

A - profile litofacjalne osadów glacifluwialnych, B - kierunki warstwowania przekątnego.

Kod litofacjalny: uziarnienie: F - mułek, S - piasek, G - żwir, D - diamikton; struktura: m - masywna, d- deformacyjna, I - warstwowanie nisko-

katowe, $\mathrm{h}$ - laminacja horyzontalna, $\mathrm{t}$ - warstwowanie rynnowe, $\mathrm{p}$ - warstwowanie płaskie, $\mathrm{r}$ - struktury riplemarkowe, $\mathrm{w}$ - laminacja falista.

Diagram rozetowy przedstawia kierunki warstwowania przekątnego osadów glacifluwialnych

Fig. 9. Lithological features of sediments at the Kalisz-Winiary site (fig. 8, series 3 )

A - directions of diagonal stratification, B - lithofacial profiles of glacifluvial sediments.

Lithofacies codes: grain-size distribution: F - silt, S - sand, G - gravel, D - diamictone; structure: $\mathrm{m}$ - massive, d - deformed, I - low angle stra-

tification, $\mathrm{h}$ - horizontal lamination, $\mathrm{t}$ - trough stratification, $\mathrm{p}$ - flat stratification, $\mathrm{r}$ - ripplemark structures, $\mathrm{w}$ - wavy lamination.

Rosetta diagram presents directions of diagonal stratification of glacifluvial sediments

dowodem procesów peryglacjalnych jest nieciągły bruk żwirowy, składający się w znacznej mierze z eologliptolitów, położony na głębokości kilkudziesięciu cm. Zdaniem autorów nie ma powodów do potwierdzenia genezy analizowanego wysokiego poziomu terasowego jako peryglacjalnej formy denudacyjnej, ani do określenia jej wieku jako vistuliański, jak to wcześniej sugerowano (Rotnicki 1966, 2011).

Badając strukturę form, zwrócono uwagę na deformacje, które mogłyby wskazywać na aktywność glacitektoniczną aktywnego lądolodu. Wcześniejsze badania nie dały jednoznacznego rozstrzygnięcia w tej kwestii. Obecnie trudno zweryfikować poglądy wcześniej prezentowane (m.in.: Rotnicki 1971, 1972; Baranowski,
Mańkowska 1979) ze względu na rekultywację starych odkrywek. Autorzy stwierdzili jednak kilka przypadków zaburzeń, które mogą być interpretowane jako glacitektoniczne, m.in. w odsłonięciach: Kalisz-Winiary (diapir piaszczysto-mułkowy, rozcinający osady glacifluwialne: fot. 6), Cienia III (liczne diapiry w brzeżnej strefie poziomu glacifluwialnego w dolinie), Opatówek (fałd), Karolew koło Koźminka (struktura monoklinalna ze strukturami spływowymi: fot. 2), Chabierów (struktury diapirów, pochylonych fałdów i serie uskoków: fot. 7). Należy zauważyć, że wiele z tych struktur trudno jednoznacznie określić jako wyłączne skutki tektoniki glacjalnej. Możliwa jest interpretacja części deformacji także jako skutków tektoniki właściwej, 


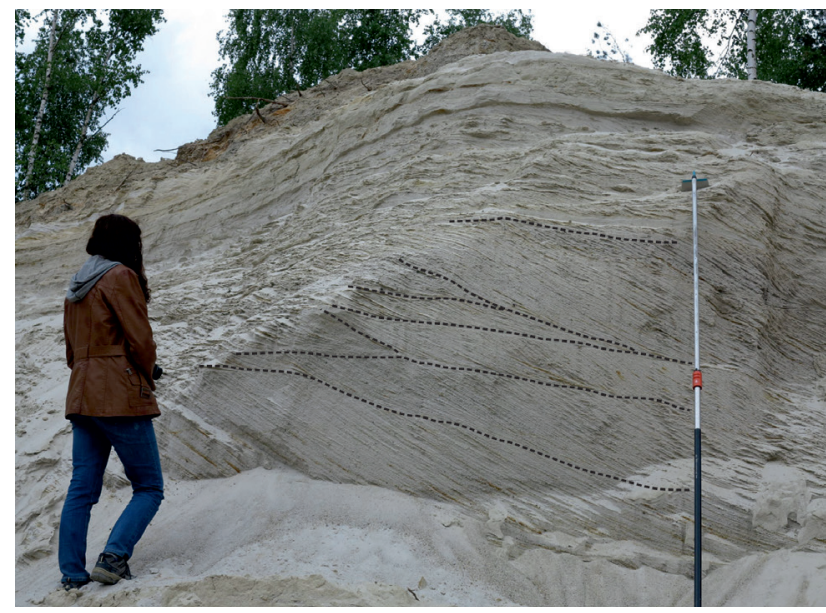

Fot. 4. Kalisz-Winiary. Warstwowanie przekątnie płaskie (Sp) piasków glacifluwialnych terasy kemowej. Zaznaczono miąższe zestawy tabularne i klinowe (fot. Rdzany 2015)

Photo 4. Kalisz-Winiary. Flat diagonal stratification (Sp) of glacifluvia sands of the kame terrace. Thick tabular and wedge sets are highlighted (photograph by Rdzany (2015)

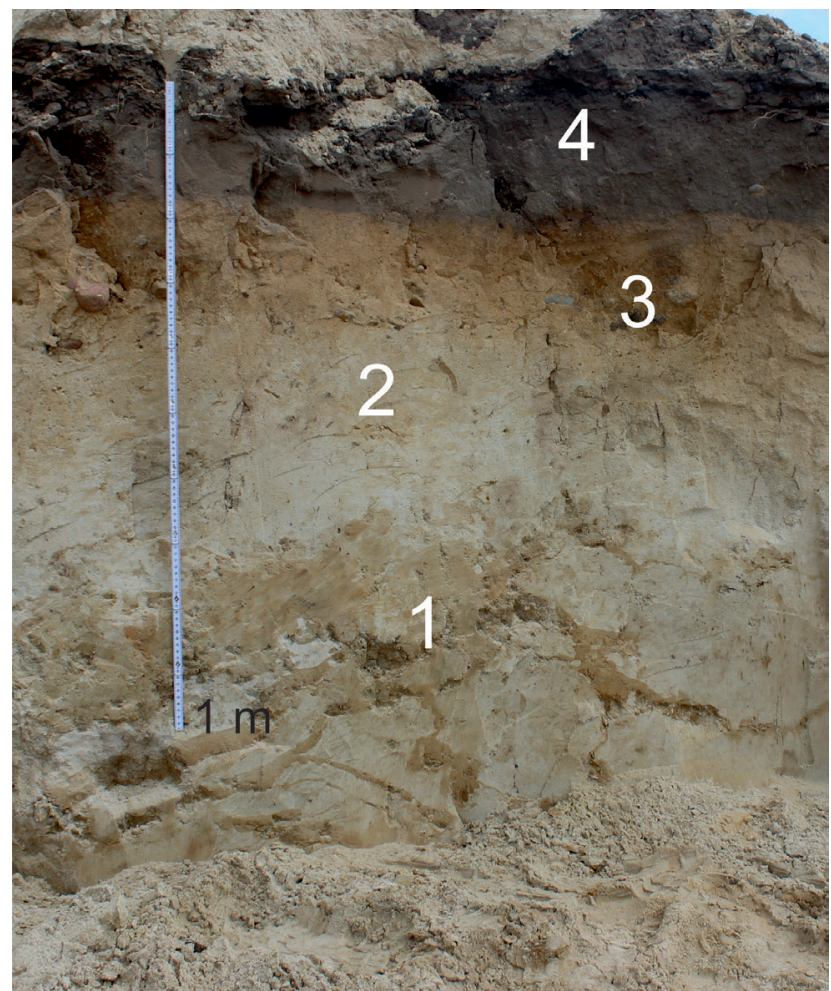

Fot. 5. Kalisz-Winiary. Górna, piaszczysto-mułkowa część terasy kemowej zmieniona przez procesy: paraglacjalne, peryglacjalne i współczesne glebowe. 1 - piaski i mułki zdeformowane para- i peryglacjalnie, 2 - piaski masywne, zmienione pedogenicznie, 3 - bruk żwirowy z eologliptolitami w piasku masywnym, 4 - poziom humusowy gleby (fot. Frydrych 2015)

Photo 5. Kalisz-Winiary. Upper, sandy-silty part of the kame terrace, transformed by paraglacial, periglacial and contemporary pedogenic processes. 1 - para- and periglacially deformed sands and silts, 2 - pedogenically altered massive sands, 3 - gravelly pavement with ventifacts in massive sand, 4 - humus level of the soil (photograph by Frydrych 2015) w szczególności wstrząsów sejsmicznych. Występują tam liczne podobieństwa cech dajek klastycznych, diapirów i innych deformacji do struktur, opisanych m.in.: ze Szwecji przez Mörnera (2005), z terenu kopalni Bełchatów - przez Van Loona (2002), Goździka i Van Loona (2007), z zachodniej Polski - przez Morettiego i Van Loona (2014), a którzy tego typu struktury wiążą z silnymi wstrząsami tektonicznymi. Deformacje te powinny być poddane dalszym badaniom.

Charakterystycznymelementem struktury większościanalizowanych form jest także występowanie deformacji drobnoskalowych, w szczególności uskoków. Łagodne uginanie się warstw, liczne pęknięcia, struktury ucieczkowe i pogrązowe są z reguły zapisem procesów działających tu synsedymentacyjnie i postsedymentacyjnie. Napotkano je niemal w każdej $z$ analizowanych odkrywek. Deformacje te dominują w strefie przypowierzchniowej, szczególnie w utworach różnofrakcyjnych, ze znacznym udziałem frakcji drobniejszych od piasku. Struktury te mają zróżnicowaną genezę. Są to zarówno struktury pochodzenia glacigenicznego (ablacyjne - rozwijające się pośród zdegradowanej pokrywy lodowej), jak i peryglacjalne (warciańskie i vistuliańskie).

\section{Wiek i geneza form wypukłych obszaru oraz ich zależność od podłoża - dyskusja}

Główne rysy rzeźby sąsiadujących wysoczyzn Kaliskiej i Tureckiej zostały ukształtowane przez lądolody oraz w znacznie mniejszym stopniu - przez procesy fluwialno-denudacyjne. Rzeźba ta $w$ analizowanym wycinku terenu wykazuje także umiarkowany związek z ukształtowaniem starszego podłoża - zarówno podplejstoceńskiego, jak i podkenozoicznego. Istnieje ogólna współkształtność trzech powierzchni: podplejstoceńskiej, podkenozoicznej i współczesnej powierzchni terenu, a także można dostrzec pewien stopień współkształtności powierzchni interplejstoceńskich (pododrzańskiej, podwarciańskiej). Największe wzniesienia pokrywają się z elewacjami starszego podłoża, choć są wyjątki, do których należy Wał Malanowski. Zbyt mała liczba danych wiertniczych nie pozwala jednak precyzyjnie przeanalizować związków z podłożem kilku dużych, pojedynczych form. Dość wyraźną zbieżność pagórków i wzgórz z formami wypukłymi podłoża czwartorzędu można stwierdzić w strefie brzeżnej monokliny przedsudeckiej w okolicach Kalisza (monoklina kalisko-złoczewska) z niecką łódzką. Formy te są położone na północnym przedłużeniu Wzgórz Ostrzeszowskich i podobnie jak one zawierają spiętrzone utwory neogenu. Profile i zarysy pagórków i wzgórz są bardziej łagodne niż elewacje podłoża czwartorzędu, co znamy od dawna zbadańneogenu(Olewicz 1961); potwierdzają to równieżbadania nowszych przekrojów geologicznych (np. Haisig, Wilanowski 2007). Jest prawdopodobne, że elewacje podłoża okolic Kalisza oraz ogólne nachylenie ku północy mogły stanowić utrudnienie w czasie kilku transgresji lądolodów; wyniesienia te sprzyjałyby także dezintegracji lodu lodowcowego w czasie deglacjacji. Również na obszarze sąsiadującym od południa dowiedziono związku występowania form, w szczególności kemów z elewacjami stropu mezozoiku. Dobrym tego przykładem jest wieloczłonowy ciąg pagórków, który można także traktować jako 20-kilometrowy wał kemowy, położony na zrębie Brzykowa na południe od Sieradza (Krzemiński 1974, 1997). 


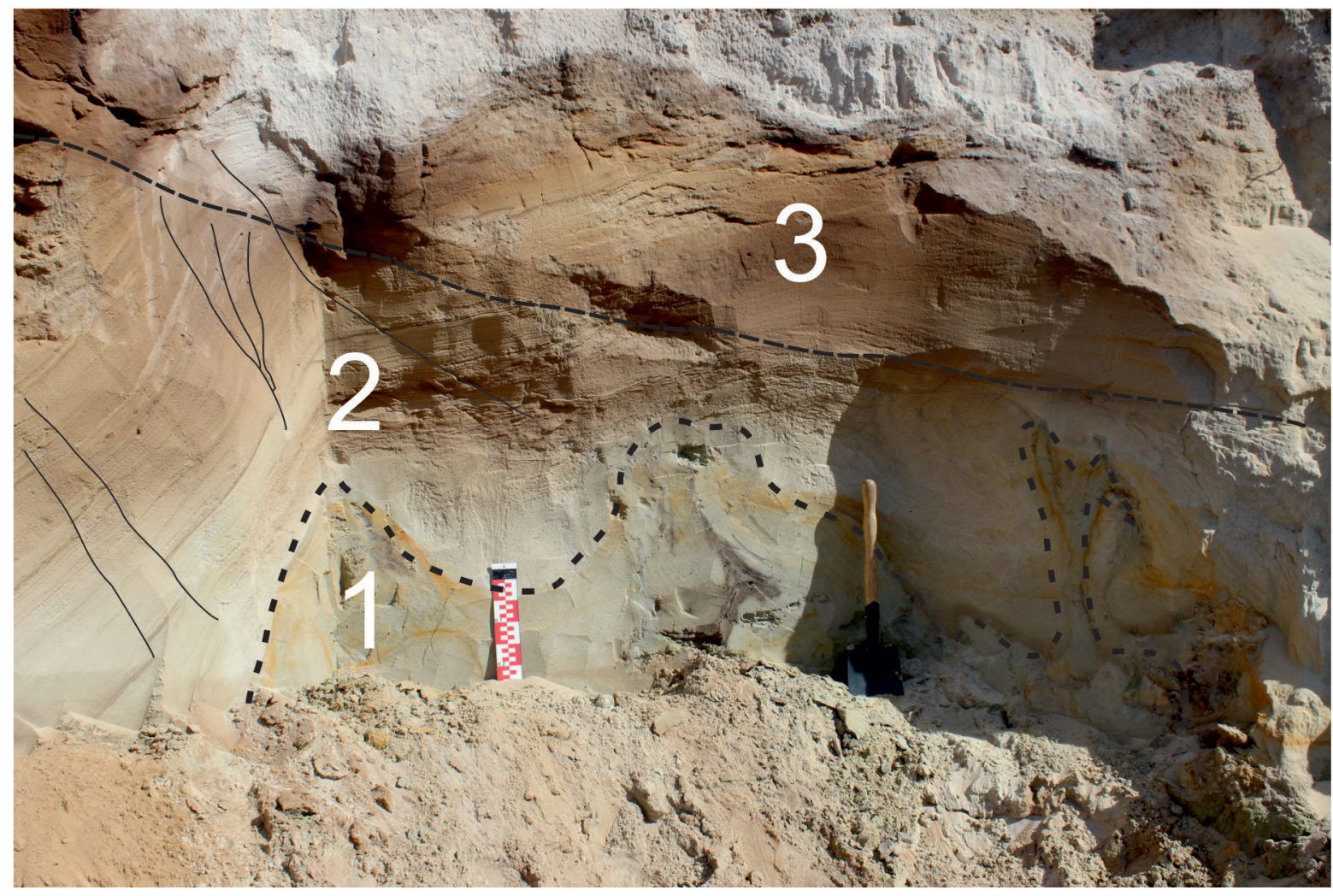

Fot. 6. Kalisz-Winiary. Fragment struktury diapirowej, rozcinającej piaski glacifluwialne terasy kemowej

1 - mułki masywne, silnie zaburzone, 2 - piaski glacifluwialne z dwiema generacjami uskoków (odwróconych i normalnych), 3 - piaski glacifluwialne, z nielicznymi uskokami normalnymi, zmienione pedogenicznie (fot. Frydrych 2015)

Photo 6. Kalisz-Winiary. Fragment of a diapiric structure, cutting through glacifluvial sands of the kame terrace 1 - massive silts, strongly deformed, 2 - glacifluvial sands with two generations of faults (reverse and normal), 3 -glacifluvial sands, with scarce normal faults, pedogenically altered (photograph by Frydrych 2015)

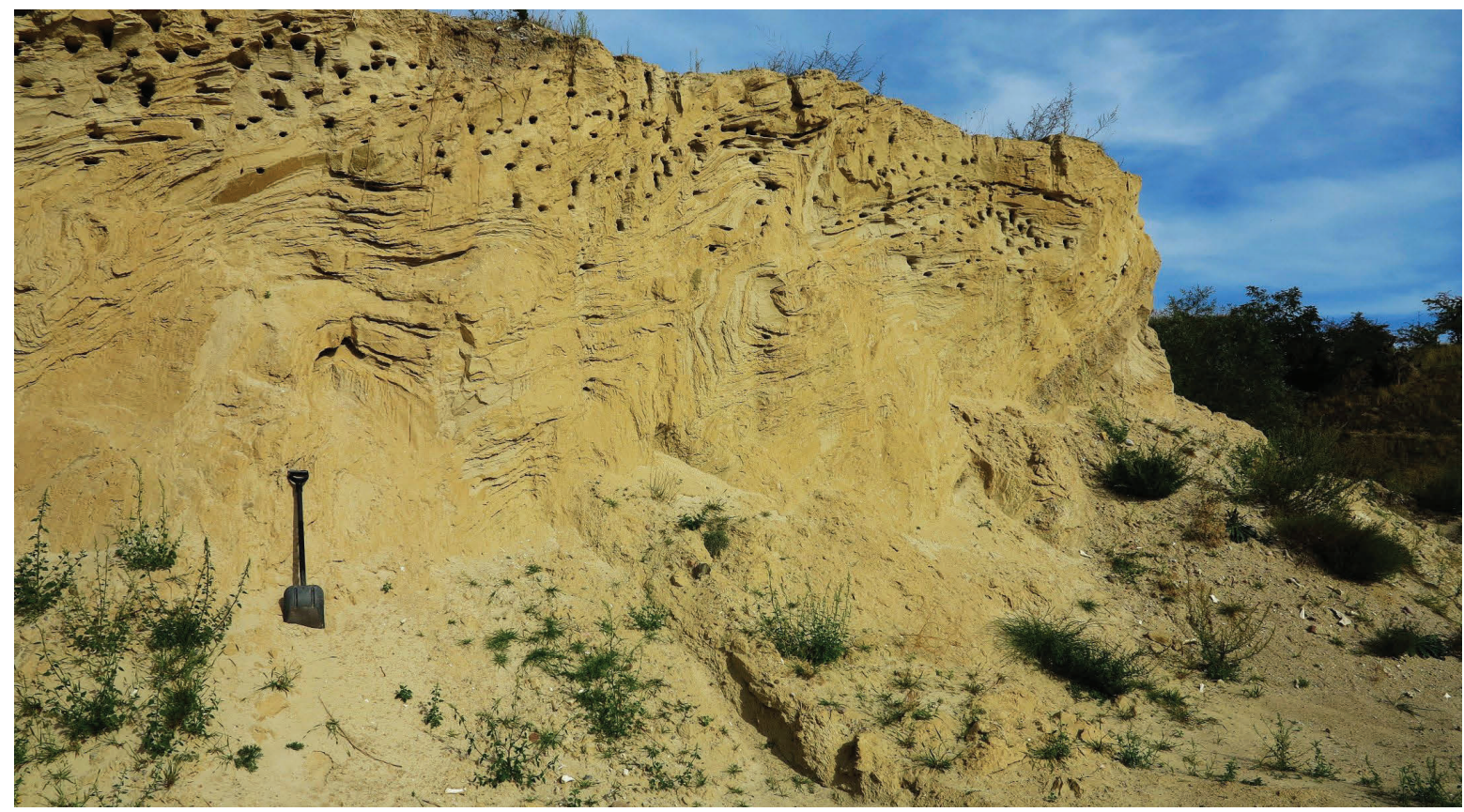

Fot. 7. Chabierów. Fragment rozległego diapiru z deformacjami fałdowymi utworów mułowo-piaszczystych w centralnej części kemu (fot. Rdzany 2015)

Photo 7. Chabierów. Fragment of a vast diapir with fold deformations of silty and sandy formations in the central part of the kame photograph by Rdzany 2015) 
W środkowej i północnej części obszaru związki rzeźby współczesnej z podłożem czwartorzędu są mniej czytelne. Nawet pod dużymi formami (Wał Malanowski) stwierdza się głębokie obniżenia i strome paleostoki podłoża, a deniwelacje podłoża kenozoiku i czwartorzędu stają się coraz większe. Jak wynika z przekrojów geologicznych, w tym Trzmiela (1992) i Nowackiego (2002), w obszarach sąsiadujących od północy, zwłaszcza w pradolinie warszawsko-berlińskiej, coraz łagodniejszej rzeźbie odpowiada znaczne urozmaicenie podłoża i coraz wyraźniejszy jego blokowy charakter.

W sprawie wieku form glacigenicznych opisywanego obszaru, jak już wspomniano, ukształtowały się dwa stanowiska. Poglądy o występowaniu tutaj linii maksymalnego zasięgu lądolodu zlodowacenia wisły w fazie leszczyńskiej, przekraczającego pradolinę warszawsko-berlińską w postaci mniej lub bardziej wysuniętego zarysu lobu konińskiego, prezentowali: Łyczewska (1977), Domosławska-Baraniecka 1967, 1969), Mańkowska (1980, 1983ab, 1985) oraz Mańkowska i Gogołek (1988). Wśród najważniejszych argumentów wspierających tę tezę, wymieniano żywość rzeźby i znaczny udział materiału miejscowego podłoża: „kredowo-trzeciorzędowego". Według Łyczewskiej (1977) był to dowód na znaczną aktywność egzaracyjną, która miałaby być typowa dla lądolodu fazy leszczyńskiej. To silna erozja w czasie interglacjału eemskiego miała doprowadzić do odsłonięcia podłoża w wielu miejscach, stąd tak znaczny udział skał miejscowych w materiale morenowym ostatniego lądolodu. Ów lob koniński miał się potem wytopić jako wielki płat lodu martwego. Lądolód sięgnął aż po okolice Koźminka (Mańkowska, Gogołek 1988, rys. 2; Gogołek, Mańkowska 1989). Według tej koncepcji, na obrzeżach tego wąskiego lobu rozwinęła się dolina marginalna, którą obecnie wykorzystuje rzeka Swędrnia. W inwentarzu form glacjalnych wyróżniono tutaj zarówno moreny czołowe, kemy, jak i moreny martwego lodu (Mańkowska 1980, 1983ab, 1985; Mańkowska, Gogołek 1988; Gogołek, Mańkowska 1989).

Petera i Forysiak (2003), dokumentując ekstraglacjalny charakter osadów vistuliańskich w stanowiskach w basenie uniejowskim w dolinie Warty, w dużej mierze przechylili dyskusję na temat zasięgu ostatniego lądolodu w kierunku poglądów, które zakładają nieprzekroczenie przez ów lądolód pradoliny warszawsko-berlińskiej w rejonie Konina. Autorzy niniejszej pracy przyłączają się do tej tezy, jednakże przeprowadzili analizy uzupełniające, aby uwzględnić więcej kryteriów geomorfologicznych. Również ze względu na niedawno wyrażone stanowisko Widery (2011) o możliwym vistuliańskim wieku masywu Złotej Góry koło Konina dyskusji na ten temat nie można uznać za zakończoną.

Kryterium jeziorności, które po raz pierwszy zastosował Tietze (1917), a w Polsce rozwinął Majdanowski (1950) do wyznaczania zasięgu ostatniego zlodowacenia, autorzy uznają za kluczowe w tym rozstrzygnięciu. Potwierdzono, że mimo bardzo urozmaiconej rzeźby jak na warciański pas morfologiczny, występuje tu typowy w tej strefie brak jezior rynnowych i innych naturalnych zbiorników polodowcowych. Na wiek starszy od zlodowacenia wisły wskazuje także zastosowanie kryterium pokrewnego: brak różnic gęstości suchych zagłębień bezodpływowych o przypuszczalnej genezie polodowcowej między hipotetycznym obszarem lobu konińskiego według Mańkowskiej (1980, 1983a), a pozostałym terenem analizy.
Poglądy o przynależności obszaru do zlodowacenia warty nie są jednak jednolite co do wiązania form z etapami tego nasunięcia i ich genezy.

Według starszych badań, formy obszaru układające się w ciąg Kalisz-Wał Malanowski były uznawane za wyznaczniki zasięgów zlodowacenia warty. Kilku autorów było zwolennikami koncepcji linii maksymalnego zasięgu. Po raz pierwszy zasięg lądolodu stadiału warty na omawianym terenie został wyznaczony przez Woldstedta (1927), który poprowadził tędy linię zasięgu, kierując ją na wschód do Łodzi i dalej w kierunku Grójca. Również Rotnicki (1971, rys. 2), opierając się na orientacji struktur glacitektonicznych, uznał, że linia: Wzgórza Ostrzeszowskie-MasanówGodziesze-Tłokinia-Wał Malanowski stanowi wschodnie obrzeżenie lobu południowowielkopolskiego stadiału warty zlodowacenia środkowopolskiego. Od Wału Malanowskiego na wschód miał się rozwinąć tzw. lob warciański. Teza o tak „małym” zasięgu lobu południowowielkopolskiego nie była później już podtrzymywana.

Krygowski (1974) wysunął tezę o czołowomorenowej genezie form w okolicach Kalisza i Warty, zaś w sprawie wieku - przypuszczenie o przynależności ich do stadiału wkry, wyróżnionego przez Różyckiego (1967). Jednakże w późniejszych badaniach - zarówno interstadiał bugo-narwi, stadiał wkry, interstadiał regimiński i stadiał mławy - które miały poprzedzać interglacjał eemski - nie doczekały się potwierdzenia swej rangi stratygraficznej innymi dowodami stratygraficznymi. W związku z tym utrwaliły się poglądy o przynależności opisywanych form do pomaksymalnej części zlodowacenia (ew. stadiału) warty.

W opinii autorów wiek rzeźby glacjalnej na podstawie cech morfologiczno-strukturalnych i porównania z wynikami badań na obszarach Wysoczyny Łaskiej można wiązać z późną częścią piętra zimnego warty, kiedy lądolód ulegał recesji. Recesja ta była przerywana krótkodystansowymi awansami lądolodu. Mimo ich dużego znaczenia morfogenetycznego, nie były to prawdopodobnie okresy znaczące w sensie stratygraficznym, dlatego też nazwano je subfazami: dobrzynki, neru i bzury (Rdzany 2009). W dorzeczu Warty zaznaczyły się wyraźnie te trzy etapy, w zasadzie ograniczone do lobu południowowielkopolskiego. Opisywany ciąg form na linii Kalisz-Wał Malanowski, nazwany przez Krzemińskiego (1997) strefą kalisko-niemysłowską, wykazuje szereg analogii do form wiązanych z subfazą bzury na wschód od doliny Warty, zaś pas pogranicza Wysoczyzny Tureckiej i Złoczewskiej - z subfazą neru (por. Rdzany 2009).

Przeprowadzone analizy: odsłonięć w formach glacigenicznych, wierceń archiwalnych i przekrojów geologicznych dokumentują dominację w budowie wewnętrznej form glacigenicznych osadów glacifluwialnych oraz akcesoryczny charakter utworów: glacilimnicznych, bezpośredniej depozycji glacjalnej i utworów ablacyjnych. Są one w znacznej mierze podobne do występujących w zachodniej i środkowej części regionu łódzkiego kemów glacifluwialnych. Jednakże budowę wewnętrzną szeregu form komplikuje dość powszechne występowanie struktur deformacyjnych, rozwiniętych w różnych skalach przestrzennych, niekiedy obejmujących cały przekrój formy. Autorzy wyrażają jednak przekonanie, że struktury deformacyjne mają znaczenie wtórne w stosunku do struktur sedymentacyjnych, ewentualnie obserwowane są przykłady występowania starszych cokołów erozyjnych z deformacjami w obrębie form warciańskich. Należy jednocześnie odnotować, 
że Haisig i Wilanowski (2007) wyróżnili tu kilka przypadkówmoren czołowych ze spiętrzenia. Ze względu na stan obecnych odsłonięć nie udało się tych stanowisk zweryfikować.

Ważną, zrekonstruowaną cechą wód transportujących badane osady glacifluwialne są stwierdzone znaczne gradienty w przepływach wód: od nisko- do wysokoenergetycznych. W profilach udokumentowano obecność strumieni o zróżnicowanej głębokości, jednak na ogół ich głębokość była niewielka, rzędu od kilku do kilkudziesięciu cm, rzadziej 1-2 m. Napotkano także zarówno głębsze i skanalizowane przepływy korytowe, jak i bardzo płytkie zalewy warstwowe. Wyrazem wysokoenergetycznych przepływów są aluwia żwirowe, zaś depozycji z niskoenergetycznych przepływów - aluwia piaszczyste. Wymienione wyżej cechy wskazują na przewagę zapisu w osadach glacifluwialnych środowisk rzek roztokowych i stożków napływowych.

Cechy osadów, tworzących analizowane formy wypukłe obszaru w powiązaniu z morfologią, skłaniają do zaklasyfikowania badanych form jako elementów strefy marginalnej, która kształtowana była głównie przez akumulację wodnolodowcową. Większość badanych form wykazuje złożoną budowę nie tylko w sensie znacznego zróżnicowania struktur akumulacji glacifluwialnej, ale także znaczącego udziału deformacji. W związku z tym formy te w większości można określić jako kemy glacifluwialne diapirowe. Istnieje jednak kilka form złożonych - nie tylko w sensie dwu- czy wieloczłonowości strukturalnej, lecz także w sensie budowy, polegającej na istnieniu różnych pięter stratygraficznych. Do tej grupy form należy m.in. Wał Malanowski, co jest faktem znanym (Chrzanowski 1980), i wzgórze w Cieni koło Kalisza. Niektóre pagórki i wały wykazują cechy typowe dla ozów (oz Rzymska) lub form ozowo-kemowych. Budowa wewnętrzna i usytuowanie przestrzenne badanych form wypukłych wskazuje na ich powstanie nie przy zwartym czole lądolodu, lecz w śródlodowych kanionach, poszerzonych szczelinach i tunelach subglacjalnych pasywnego bądź martwego lądolodu warciańskiego, w zdezintegrowanym pasie brzeżnym czaszy lądolodu o szerokości kilku do kilkunastu kilometrów.

Większe deformacje występują w głębszych partiach form, ale są także takie, które dochodzą do powierzchni terenu. Niektóre ze struktur deformacyjnych mogą wskazywać na oddziaływanie dynamiki głębszego podłoża na lądolód, osady i formy zlodowacenia warty. O wpływie tektoniki właściwej na deformacje okolic Kalisza i Wzgórz Ostrzeszowskich zwracali już uwagę Olewicz (1961) oraz Baranowski i Mańkowska (1979, s. 7). Późniejsze badania pozwoliły ustalić, że centralna Polska była objęta kilkoma etapami aktywności tektonicznej w okresie postlaramijskim. Widera i Hałuszczak (2011) wyróżnili w centralnej Polsce cztery fazy, przy czym zakres fazy ostatniej (Fourth deformational stage) związali z okresem od zlodowacenia warty do współczesności. W szeroko rozumianych okolicach Kalisza były odnotowane spostrzeżenia o aktywności tektonicznej w młodszym czwartorzędzie, zarówno w postaci powolnych ruchów pionowych, jak i wstrząsów sejsmicznych.

Aktywność tektoniczna w okresie deglacjacji była prawdopodobnie powiązana z efektem glaciizostatycznym, co wydaje się typowe dla wielu obszarów zlodowaceń kontynentalnych, zgodnie z koncepcją sejsmotektoniki deglacjacyjnej (Muir-Wood 2000). Wielokrotnie dochodziło do interakcji lądolód/podłoże, nie tylko w wyniku objęcia transgresją lądolodu całego obszaru (ostatni raz w piętrze zimnym warty), lecz także wówczas, kiedy lądolód tylko przybliżał się do obszaru (po raz ostatni w fazie leszczyńskiej zlodowacenia wisły) - również miały miejsce efekty glaciizostatyczne. Także i w okresach interglacjalnych powolne ruchy pionowe obejmowały analizowany teren.

Analizowany obszar mógł zostać objęty wstrząsami sejsmicznymi zarówno w trakcie zlodowacenia warty, jak i w okresie postwarciańskim. Jest prawdopodobne, że w wyniku wstrząsów, zwłaszcza w piętrze warty powstały struktury deformacyjne, które do tej pory mogły być uważane wyłącznie za zaburzenia glacitektoniczne. Należy przypomnieć, że zapis wstrząsów tektonicznych w czasie piętra warty dokumentowano kilkakrotnie w środkowej Polsce, głównie w rowach tektonicznych Kleszczowa (m.in.: Van Loon 2002; Goździk i Van Loon 2007; Gruszka 2007; Gruszka i Van Loon 2007) i Adamowa (Pawłowski et al. 2013), ale także w innych sytuacjach morfologiczno-tektonicznych (Baraniecka 1975). Badania sejsmitów w osadach jeziornych zastoiska koźmińskiego, przeprowadzone przez Peterę-Zganiacz z zespołem (Pawłowski et. al. 2013), wskazują na zapis trzęsień o magnitudzie 5,5-8, które nie tylko powodowały resuspensję osadów i powstanie horyzontu deformacji, lecz także wywoływały szereg zmian w warunkach funkcjonowania ubogiego jeszcze środowiska biotycznego, m.in. okresowy zanik Cladocera.

Istnieje szereg przesłanek wskazujących również na współczesną dynamikę litosfery obszaru i jego sąsiedztwa. Elewacja konińska na północy (aktywna od fazy laramijskiej: Widera 1998) i Wyżyna Wieluńska na południu (Krzemiński 1974; Forysiak 2005) są uważane za obszary o powtarzających się tendencjach wznoszących. Podkreśla się także, że niektóre lokalne formy wykazują tendencje obniżające, np. obniżenie torfowiska w Bartochowie (Forysiak 2005). Potwierdzają to m.in. pomiary grawimetryczne, które wykazują także znaczne gradienty lokalnych ruchów w południowej części obszaru (Wyrzykowski 1990; Kowalczyk, Rapiński 2011).

Struktury deformacyjne w postaci diapirów, diapirodajek, dajek, fałdów, łusek o wymiarach rzędu kilkudziesięciu metrów oraz liczne drobne struktury (pogrązowe, ucieczkowe i in.), nie wykazują jednoznacznego powiązania z aktywnością czoła lądolodu. Przykłady opisane z Dusznik koło Warty i Siedlątkowa (Załoba i Czubla 1995; Rdzany 2009, s. 222), gdzie w budowie diapirów uczestniczy glina glacjalna ścinająca utwory glacifluwialne, należy do wyjątków. Dominują jednak struktury (np. fot. 6, 7 i 8), które powstały przy przeważającej składowej pionowej, nawet jeśli wykazują niewielką asymetrię. $W$ ich budowie często uczestniczą mułki, niezależnie od osadów bardziej grubofrakcyjnych. Na powierzchni erozyjnej, która je ścina, stwierdzono cienkie pokrywy glacifluwialne, zasadniczo o podobnych cechach litologicznych do niżej leżących. Deformacje te powstały głównie pod koniec akumulacji glacifluwialnej danej formy, kiedy partie osadów o dużych różnicach gęstości w sąsiednich litosomach były silnie nawodnione, o czym świadczą m.in. liczne przejawy fluidyzacji osadów. Można postawić hipotezę o możliwości wystąpienia dwóch głównych czynników spustowych tych deformacji: nacisków lodu lodowcowego (zarówno tangencjalnych, jak i pionowych), jak i trzęsień ziemi. Taką interpretację już przedstawiano dla struktur diapirowych w Siedlątkowie na krawędzi doliny Warty i w Dusznikach w obrębie tzw. pagórków warciańskich (Rdzany 2009). 
Występują tu analogie do opisanych przez Goździka i VanLoona (2007) z terenu kopalni Bełchatów, a także do vistuliańskich i holoceńskich deformacji opisanych ze Szwecji przez Mörnera (2005), który je wiąże z silnymi wstrząsami tektonicznymi. Można przypuszczać, że wiek tych struktur jest starszy od horyzontu zaburzeń opisanych z zastoiska koźmińskiego.

\section{Wnioski końcowe}

- Badany obszar znajduje się w strefie rosnącego w kierunku południowym wpływu podłoża podkenozoicznego na formy rzeźby i osady glacigeniczne.

- Nie stwierdzono wiarygodnych przesłanek (morfologicznych, litologicznych, stratygraficznych), aby na analizowany teren sięgnął lądolód zlodowacenia wisły w którejkolwiek fazie.

- Największy wpływ na ukształtowanie obecnej powierzchni terenu miało zlodowacenie warty. Wiek rzeźby glacjalnej, w szczególności tzw. strefy kaliskiej na linii Kalisz-Wał Malanowski, na podstawie cech morfologiczno-strukturalnych i porównania z wynikami badań na obszarach sąsiednich, związany jest prawdopodobnie z późną częścią piętra zimnego warty, w szczególności z subfazą bzury (por. Rdzany 2009).

- Dominująca część badanych osadów powstała w środowisku glacifluwialnym. Utwory te, budujące kemy (pagórki, wały, wzgórza i terasy kemowe), ozy, pagórki i wały glacimarginalne oraz formy złożone, wskazują na dominację litosomów piaszczystych nad żwirowymi i mułkowymi. Pośród struktur przeważają przekątne warstwowania tabularne, rynnowe i niskokątowe. Stanowią one zapis akumulacji zachodzącej w korytach o zmiennej głębokości oraz podczas płytkich i rozległych zalewów warstwowych na stożkach napływowych.

- W strukturze form znaczący jest udział zaburzeń, a ich zróżnicowanie genetyczne - wyjątkowo duże. Największe amplitudy, niekiedy obejmujące cały przekrój formy osiągają zaburzenia glacitektoniczne sensu lato. W górnych częściach profili zaznaczają się skutki warciańskich procesów paraglacjalnych oraz warciańskich i vistuliańskich procesów peryglacjalnych.

- Wiele cech form występujących na badanym obszarze ma cechy charakterystyczne dla kemów glacifluwialnych diapirowych. Formy o znacznych rozmiarach posiadają budowę i genezę złożoną, a zaklasyfikowanie ich do wąskiej kategorii genetycznej (np. kem diapirowy, morena spiętrzenia, morena martwego lodu) stanowiłoby nadmierne uproszczenie.

- W czasie recesji lądolodu mogło dojść do stosunkowo silnych wstrząsów tektonicznych, które przyśpieszały deglacjację i spowodowały powstanie struktur deformacyjnych w osadach kalisko-niemysłowskiej strefy deglacjacyjnej.

- Przeprowadzone badania prowadzą do wniosku, że zachowanie pierwotnych cech rzeźby glacjalnej jest lepsze niż dawniej sądzono. W szczególności teza o występowaniu rozległych spłaszczeń denudacyjnych, w tym położonych w wyższych partiach dolin rzecznych, nie znajduje potwierdzenia.

\section{Literatura}

Baraniecka, M., 1975. Zależność wykształcenia osadów czwartorzędowych od struktur i dynamiki podłoża w środkowej części Niżu Polskiego. Biuletyn Instytutu Geologicznego 288, 5-97.

Baraniecka, M.D., Sarnacka, D., 1971. Stratygrafia czwartorzędu i paleogeografia dorzecza Widawki. Biuletyn Instytutu Geologicznego 254, 157-269.

Baranowski, J., Mańkowska, A., 1970. Mapa geologiczna Polski w skali 1:200 000, ark. Kalisz.

Baranowski, J., Mańkowska, A., 1972. Mapa geologiczna Polski w skali 1:200 000, ark. Kalisz.

Baranowski, J., Mańkowska, A., 1979. Objaśnienia do Mapy geologicznej Polski 1:200 000, arkusz Kalisz. Wydawnictwa Geologiczne, Warszawa, 1-47.

Bartkowski, T., 1968. Kemy na obszarze Niziny Wielkopolskiej a deglacjacja. Badania Fizjograficzne nad Polską Zachodnia, 3-39.

Chrzanowski, J., 1980. Formy deglacjacji na Wale Malanowskim i w jego otoczeniu. Acta Geographica Lodziensia 43, 1-104.

Czyż, J., Forysiak, J., Kamiński, J., Klatkowa, H., 2004. Szczegółowa mapa geologiczna Polski, arkusz Dobra (587), Wydawnictwa Geologiczne, Warszawa.

Czyż, J., Forysiak, J., Kamiński, J., Klatkowa, H., 2008. Objaśnienia do Szczegółowej mapy geologicznej Polski, arkusz Dobra (587), Wydawnictwa Geologiczne, Warszawa, 1-39.

Domosławska-Baraniecka, M.D., 1967. Konin-Koło. Zasięg zlodowacenia a pradolina pod Kołem. Przewodnik XLI Zjazdu Pol. Tow. Geol., Wydawnictwa Geologiczne, 171-174.

Domosławska-Baraniecka, M.D., 1969. Ze stratygrafii i rozwoju czwartorzędu południowych Kujaw. Przewodnik XLI Zjazdu Pol. Tow. Geol., Wydawnictwa Geologiczne, Konin, 49-58.

Dylik, J., 1953. O peryglacjalnym charakterze rzeźby środkowej Polski, Acta Geographica Universitatis Lodziensis 4, 1-109.

Eyles, N., Eyles, C.H., Miall, A.D., 1983. Lithofacies types and vertical profile models; an alternative approach to the description and environmental interpretation of glacial diamict and diamictite sequences. Sedimentology 30, 393-410.

Folk, R.L., Ward, W.C., 1957. Brazos river bar: a study in the significance of grain size parameters. Journal of Sedimentary Petrology 27, 3-26.

Forysiak, J., 2005. Rozwój doliny Warty między Burzeninem a Dobrowem po zlodowaceniu warty, Acta Geographica Lodziensi 90, 1-116.

Gogołek, W., Mańkowska, A. 1989. Zlodowacenie północnopolskie Wysoczyzny Tureckiej w świetle nowych danych. Kwartalnik Geologiczny 33, 573-586.

Goździk, J., van Loon, A.J.T., 2007. The origin of a giant downward directed clastic dyke in a kame (Bełchatów mine, central Poland). Sedimentary Geology 193, 71-79.

Gruszka, B., 2007. The Pleistocene glaciolacustrine sediments in the Betchatów mine (central Poland): Endogenic and exogenic controls. Sedimentary Geology 193, 149-166.

Gruszka, B., van Loon, A.T., 2007. Pleistocene glaciolacustrine breccias of seismic origin in an active graben (central Poland). Sedimentary Geology 193, 93-104.

Haisig, J., Wilanowski, S., 2007. Szczegółowa mapa geologiczna Polski 1:50 000, arkusz Kalisz (622). Wydawnictwa Geologiczne, Warszawa.

Klatkowa, H., 1972. Paleogeografia Wyżyny Łódzkiej i obszarów sąsiednich podczas zlodowacenia warciańskiego. Acta Geographica Lodziensia 28, 1-220.

Klatkowa, H., 1988. Objaśnienia do Szczegółowej mapy geologicznej Polski 1:50 000, arkusz Łask (663). Wydawnictwa Geologiczne, Warszawa, 1-59.

Klatkowa, H., Załoba, M., 1991. Kształtowanie budowy geologicznej i rzeźby południowego obrzeżenia Basenu Uniejowskiego. In: Stankowski, W. (Ed.) Przemiany środowiska geograficznego obszaru Konin-Turek. Instytut Badań Czwartorzędu UAM, Poznań, 33-44.

Kłysz, P., 1981. Morfogeneza zespołu form marginalnych między Koninem, Kołem a Turkiem. Seria Geografia, Uniwersytet im. Adama Mickiewicza, Poznań, 1-87.

Kondracki, J., 2001. Geografia regionalna Polski. Wydawnictwo Naukowe PWN, Warszawa, 1-440.

Kowalczyk, K., Rapiński, J., 2011. New elaboration of gradient map of vertical crustal movements in the territory of Poland. Faculty of Technical Science, University of Warmia and Mazury in Olsztyn, 245-254. 
Krygowski, B., 1974. Niektóre problemy z morfodynamiki Niziny Wielkopolskiej. Badania Fizjograficzne nad Polską Zachodnią, Geografia fizyczna 27A, 89-156.

Krzemiński, T., 1974. Geneza młodoplejstoceńskiej rzeźby glacjalnej w dorzeczu środkowej Warty. Acta Geographica Lodziensia 33, 1-171.

Krzemiński, T., 1997. Cechy rozwoju i zaniku lądolodu warciańskiego w środkowej Polsce. Acta Universitatis Lodziensis, Folia Geographica Physica 1, 47-65. URI: 11089/2878.

Krzemiński, T., Bezkowska, G., 1987. Szczegółowa mapa geologiczna Polski 1:50 000, ark. Widawa (698)

Lencewicz, S., 1927. Dyluwium i morfologia środkowego Powiśla. Prace Państwowego Instytutu Geologicznego 2(2), 67-220.

Łyczewska, J., 1977. Dynamika frontalna lądolodu bałtyckiego w okolicy Koła nad Wartą. Studia Geologica Polonica 52, 281-296.

Majdanowski, S., 1950. Zagadnienie rynien jeziornych na Niżu Europejskim. Badania Fizjograficzne nad Polską Zachodnią 2, 35-122.

Mańkowska, A., 1980. Mapa geologiczna Polski w skali 1:200 000, ark. Konin. Wyd. A.

Mańkowska, A., 1983a. Objaśnienia do Szczegółowej mapy geologiczna Polski 1:50 000, ark. Tuliszków (549). Wydawnictwa Geologiczne, Warszawa, 1-124.

Mańkowska, A., 1983b. Szczegółowa mapa geologiczna Polski 1:50 000, ark. Tuliszków (549).

Mańkowska, A., 1985. Szczegółowa mapa geologiczna Polski 1:50 000, ark. Kotwasice (586).

Mańkowska, A., Gogołek, W., 1988. Objaśnienia do Szczegółowej Mapy Geologicznej Polski 1:50 000, ark. Kotwasice (586). Wydawnictwa Geologiczne, Warszawa, 1-89.

Miall, A.D., 1978. Lithofacies types and vertical profile models in braided river deposits: a summary. In. Miall, A.D. (Ed.) Fluvial Sedimentology. Canadian Society of Petroleum Geologists, 597-604.

Moretti, M., Van Loon, A., 2014. Restrictions to the application of „diagnostic" criteria for reco gnizing ancient seismites. Journal of Palaeogeography 3, 162-173.

Mörner, N.A., 2005. An interpretation and catalogue of paleoseismicity in Sweden. Tectonophysics 408, 265-307.

Muir-Wood, R., 2000. Deglaciation seismotectonics: a principal influence on intraplate seismogenesis at high latitudes. Quaternary ScienceReviews 19, 1399-1411.

Nowacki, K., 2002. Szczegółowa mapa geologiczna Polski w skali 1:50 000 ark. Rychwat (548).

Olewicz, Z.R., 1961. Glacitektonika iłów poznańskich w okolicy Kalisza. Rocznik Polskiego Towarzystwa Geologicznego 31, 443-460.

Passega, R., Byramjee, R., 1969. Grain-size image of clastic deposits. Sedimentology 13, 233-252.

Pawłowski, D., Gruszka, B., Gallas, H., Petera-Zganiacz, J., 2013. Changes in the biota and sediments of glacial Lake Koźmin, Poland, during the late Saalian (Illinoian). Journal of Paleolimnology 49, 679-696.

Petera, J., Forysiak, J., 2003. The problem of the Last Glaciation extent in Central Poland. Geological Quaterly 47(4), 357-366.

Rdzany, Z., 1997. Kształtowanie rzeźby terenu między górną Rawką a Pilicą w czasie zaniku lądolodu warciańskiego. Acta Geographica Lodziensia 73, Łódź. DOI: 10.13140/RG.2.1.4361.2885.

Rdzany, Z., 2009. Rekonstrukcja przebiegu zlodowacenia warty w regionie łódzkim. Wydawnictwo Uniwersytetu Łódzkiego, Łódź. DOI 10.13140/RG.2.1.4504.4965.
Rdzany, Z., 2015. The role of the paraglacial environment in the transformation of glacial Wartanian relief in Poland. Bulletin of Geography, Physical Geography Series 8, 33-45.

Rdzany, Z., Szmidt, A., Tarnawska, K., 2013. Rola procesów glacjalnych w kształtowaniu rzeźby południowego obrzeżenia Kotliny Kolskiej. Biuletyn Uniejowski 2, 5-21. URI: 11089/3129.

Rotnicki, K., 1966. Rzeźba Wzgórz Ostrzeszowskich jako rezultat rozwoju stoku podczas Würmu. Prace Komisji Geograficzno-Geologicznej PTPN. Poznań, 5(2), 1-260.

Rotnicki, K., 1971. Struktura deformacji w strefie wtórnego kontaktu łusek glacitektonicznych w Winiarach koło Kalisza. Seria A 24, 199-236.

Rotnicki, K., 1972. Struktura glacitektonicznego uskoku o poślizgu poziomym w Jastrzębnikach koło Kalisza. Poznańskie TPN Prace Komisji Geograficzno-Geologicznej 13, 191-209.

Rotnicki, K., 2011. Geomorfologia południowo-wschodniej Wielkopolski (1965). Mapa numeryczna.

Różycki, S.Z., 1967. Plejstocen Polski Środkowej. Państwowe Wydawnictwo Naukowe, Warszawa, 1-251.

Różycki, S.Z., 1972. Plejstocen Polski Środkowej na tle przeszłości w górnym trzeciorzędzie. Państwowe Wydawnictwo Naukowe, Warszawa, $1-316$

Tarnawska, K., 2013. Geneza form rzeźby glacjalnej na pograniczu Wysoczyzny Kaliskiej i Tureckiej. Uniwersytet Łódzki, Praca magisterska: Katedra Geografii Fizycznej.

Tietze, O., 1917. Die äussersten Endmoränen der jüngsten Vereisung Norddeutschlands. Geologische Rundschau 8, 35-35.

Trzmiel, B., 1992. Szczegółowa mapa geologiczna Polski w skali 1:50 000, ark. Turek (550).

Trzmiel, B., 1995. Szczegółowa mapa geologiczna Polski w skali 1:50 000, ark. Stawiszyn (585)

Van Loon, A., 2002. Soft-sediment deformations in the Kleszczów Graben (central Poland). Sedimentary Geology 147, 57-70.

Widera, M., 1998. Ewolucja paleomorfologiczna i paleotektoniczna elewacji konińskiej. Geologos 3, 55-103.

Widera, M., 2007. Litostratygrafia i paleotektonika kenozoiku podplejstoceńskiego Wielkopolski, Geologia. Wydawnictwo Naukowe UAM, 1-224.

Widera, M., 2011. Geomorphology, sedimentology and origin of the glacigenic Złota Góra hills near Konin (Central Poland). Geological Quaterly 55(3), 235-252.

Widera, M., Hałuszczak, A., 2011. Stages of the Cenozoic tectonics in central Poland: examples from selected grabens. Zeitschrift der Deutschen Gesellschaft für Geowissenschaften 162, 203-215. DOI:10.1127/1860-1804/2011/0162-0203

Woldstedt, P. 1927. Die Gliederung des Jüngeren Diluviums in Norddeutschland und seine Parallelisierung mit anderen Glazialgebieten. Zeitschrift der Deutschen Geologischen Gesellschaft, 51-52.

Wyrzykowski, T., 1990. Opracowanie map gradientów prędkości współczesnych pionowych ruchów powierzchni skorupy ziemskiej na obszarze Polski. Prace Instytutu Geodezji i Kartografii 37, 1-2.

Załoba, M., Czubla, P., 1995. Examples of deformation strutures in deposits of different ages in the vicinity of the Uniejów basin and the eastern part of the Turek Plateau. Acta Geographica Lodziensia 68 197-212. 